\title{
Volcanism in Iceland in historical time: Volcano types, eruption styles and eruptive history
}

\author{
T. Thordarson ${ }^{\mathrm{a}, *}, \mathrm{G}$. Larsen ${ }^{\mathrm{b}}$ \\ a School of GeoSciences, University of Edinburgh, Edinburgh EH9 3JW, United Kingdom \\ ${ }^{\mathrm{b}}$ Institute of Earth Sciences, University of Iceland, IS-101 Reykjavik, Iceland
}

Received 20 June 2006; received in revised form 18 August 2006; accepted 5 September 2006

\begin{abstract}
The large-scale volcanic lineaments in Iceland are an axial zone, which is delineated by the Reykjanes, West and North Volcanic Zones (RVZ, WVZ, NVZ) and the East Volcanic Zone (EVZ), which is growing in length by propagation to the southwest through pre-existing crust. These zones are connected across central Iceland by the Mid-Iceland Belt (MIB). Other volcanically active areas are the two intraplate belts of Öræfajökull (ÖVB) and Snæfellsnes (SVB). The principal structure of the volcanic zones are the 30 volcanic systems, where 12 are comprised of a fissure swarm and a central volcano, 7 of a central volcano, 9 of a fissure swarm and a central domain, and 2 are typified by a central domain alone.

Volcanism in Iceland is unusually diverse for an oceanic island because of special geological and climatological circumstances. It features nearly all volcano types and eruption styles known on Earth. The first order grouping of volcanoes is in accordance with recurrence of eruptions on the same vent system and is divided into central volcanoes (polygenetic) and basalt volcanoes (monogenetic). The basalt volcanoes are categorized further in accordance with vent geometry (circular or linear), type of vent accumulation, characteristic style of eruption and volcanic environment (i.e. subaerial, subglacial, submarine).

Eruptions are broadly grouped into effusive eruptions where $>95 \%$ of the erupted magma is lava, explosive eruptions if $>95 \%$ of the erupted magma is tephra (volume calculated as dense rock equivalent, DRE), and mixed eruptions if the ratio of lava to tephra occupy the range in between these two end-members. Although basaltic volcanism dominates, the activity in historical time (i.e. last 11 centuries) features expulsion of basalt, andesite, dacite and rhyolite magmas that have produced effusive eruptions of Hawaiian and flood lava magnitudes, mixed eruptions featuring phases of Strombolian to Plinian intensities, and explosive phreatomagmatic and magmatic eruptions spanning almost the entire intensity scale; from Surtseyan to Phreatoplinian in case of "wet" eruptions and Strombolian to Plinian in terms of "dry" eruptions. In historical time the magma volume extruded by individual eruptions ranges from $\sim 1 \mathrm{~m}^{3}$ to $\sim 20 \mathrm{~km}^{3}$ DRE, reflecting variable magma compositions, effusion rates and eruption durations.

All together 205 eruptive events have been identified in historical time by detailed mapping and dating of events along with extensive research on documentation of eruptions in historical chronicles. Of these 205 events, 192 represent individual eruptions and 13 are classified as "Fires", which include two or more eruptions defining an episode of volcanic activity that lasts for months to years. Of the 159 eruptions verified by identification of their products 124 are explosive, effusive eruptions are 14 and mixed eruptions are 21. Eruptions listed as reported-only are 33. Eight of the Fires are predominantly effusive and the remaining five include explosive activity that produced extensive tephra layers. The record indicates an average of 20-25 eruptions per century in Iceland, but eruption frequency has varied on time scale of decades. An apparent stepwise increase in eruption frequency is observed over the last 1100 years that reflects improved documentation of eruptive events with time. About $80 \%$ of the verified eruptions took place on the EVZ where the four most active volcanic systems (Grímsvötn, Bárdarbunga-Veidivötn, Hekla and Katla) are located
\end{abstract}

\footnotetext{
* Corresponding author. Tel.: +44 131650 8526; fax: +44 1316683184.

E-mail address: thor.thordarson@ed.ac.uk (T. Thordarson).
} 
and $9 \%, 5 \%, 1 \%$ and $0.5 \%$ on the RVZ-WVZ, NVZ, ÖVB, and SVB, respectively. Source volcano for $\sim 4.5 \%$ of the eruptions is not known.

Magma productivity over 1100 years equals about $87 \mathrm{~km}^{3}$ DRE with basaltic magma accounting for about $79 \%$ and intermediate and acid magma accounting for $16 \%$ and 5\%, respectively. Productivity is by far highest on the EVZ where $71 \mathrm{~km}^{3}(\sim 82 \%)$ were erupted, with three flood lava eruptions accounting for more than one half of that volume. RVZ-WVZ accounts for $13 \%$ of the magma and the NWZ and the intraplate belts for $2.5 \%$ each. Collectively the axial zone (RVZ, WVZ, NVZ) has only erupted $15-16 \%$ of total magma volume in the last 1130 years.

(c) 2006 Elsevier Ltd. All rights reserved.

Keywords: Eruption frequency; Magma production rates; Volcanic systems; Explosive volcanism; Effusive volcanism

\section{Introduction}

Volcanism in Iceland is diverse for an oceanic island and has featured nearly all volcano types and eruption styles known on Earth (Thorarinsson and Sæmundsson, 1979; Thorarinsson, 1981). The volcano types range from archetypal mafic lava shields to classical conical-shape stratovolcanoes, whereas the styles of volcanic activity span the spectrum of effusive as well as phreatomagmatic and magmatic explosive eruptions in the settings of subaerial to subglacial and submarine environments. Although volcanism is typified by effusive basalt eruptions, it is also characterized by a range of explosive styles that includes felsic eruptions of subplinian and Plinian intensities as well as the renowned mafic subglacial phreatomagmatic eruptions. The effects of many Icelandic eruptions have been felt on a hemispheric scale and the very largest ones may have had global impact.

Just over 25 years ago, Thorarinsson and Sæmundsson (1979), published a decisive paper titled "Volcanic activity in historical times", outlining the contemporary understanding of Icelandic volcanoes. Since then significant advances have been made and it is time to present a new review of the volcanic activity in Iceland in historical times, which is the principal objective of this paper.

\section{Geology of Iceland}

\subsection{Geologic setting}

The Iceland basalt plateau is situated at the junction of two large submarine physiographic structures, the MidAtlantic Ridge and the Greenland-Iceland-Faeroe Ridge (Fig. 1). It rises more than $3000 \mathrm{~m}$ above the surrounding sea floor, has crustal thickness of $10-40 \mathrm{~km}$ and covers about $350,000 \mathrm{~km}^{2}$ (e.g. Gudmundsson, 2000 and references therein). About $30 \%$ of this area $\left(\sim 103,000 \mathrm{~km}^{2}\right)$ is above sea level, the remainder forms the $50-200 \mathrm{~km}$ wide shelf around the island. The construction of the Iceland basalt plateau is by most considered to be the product of an interaction between a spreading plate boundary and a mantle plume (e.g. Vink, 1984; White et al., 1995; Bjarnason et al., 1996; Wolfe et al., 1997; Allen et al., 1999). The construction is thought to have begun about 24 million years ago (e.g. Sæmundsson, 1978, 1979; Jóhannesson, 1980; Kristjánsson, 1982; Óskarsson et al., 1985), although the oldest rocks exposed on land in Iceland are only 14-16 million years old (e.g. Moorbath et al., 1968; McDougall et al., 1984; Watkins and Walker, 1977). The present and past geological architecture of Iceland is a representation of this interaction and the most obvious manifestation is the elevation of the plateau above the surrounding sea floor as well as the configuration of active volcanic zones and belts (Fig. 1). The Iceland mantle plume has been active for the last 65 million years and formed the $\sim 2000 \mathrm{~km}$ long North Atlantic Igneous Province (NAIP), including Iceland which is the only part that is still active (e.g. Saunders et al., 1997).

\subsection{Regions of active volcanism}

Current distribution and arrangement of active volcanism in Iceland results from superposition of the spreading plate boundary over the Iceland mantle plume as well as the relative motion of these two structures. The surface expressions of this interaction are the neovolcanic zones; a discrete $15-50 \mathrm{~km}$ wide belts of active faulting and volcanism (e.g. Sæmundsson, 1979; Jóhannesson, 1980; Vink, 1984; Óskarsson et al., 1985; Hardarson et al., 1997; 


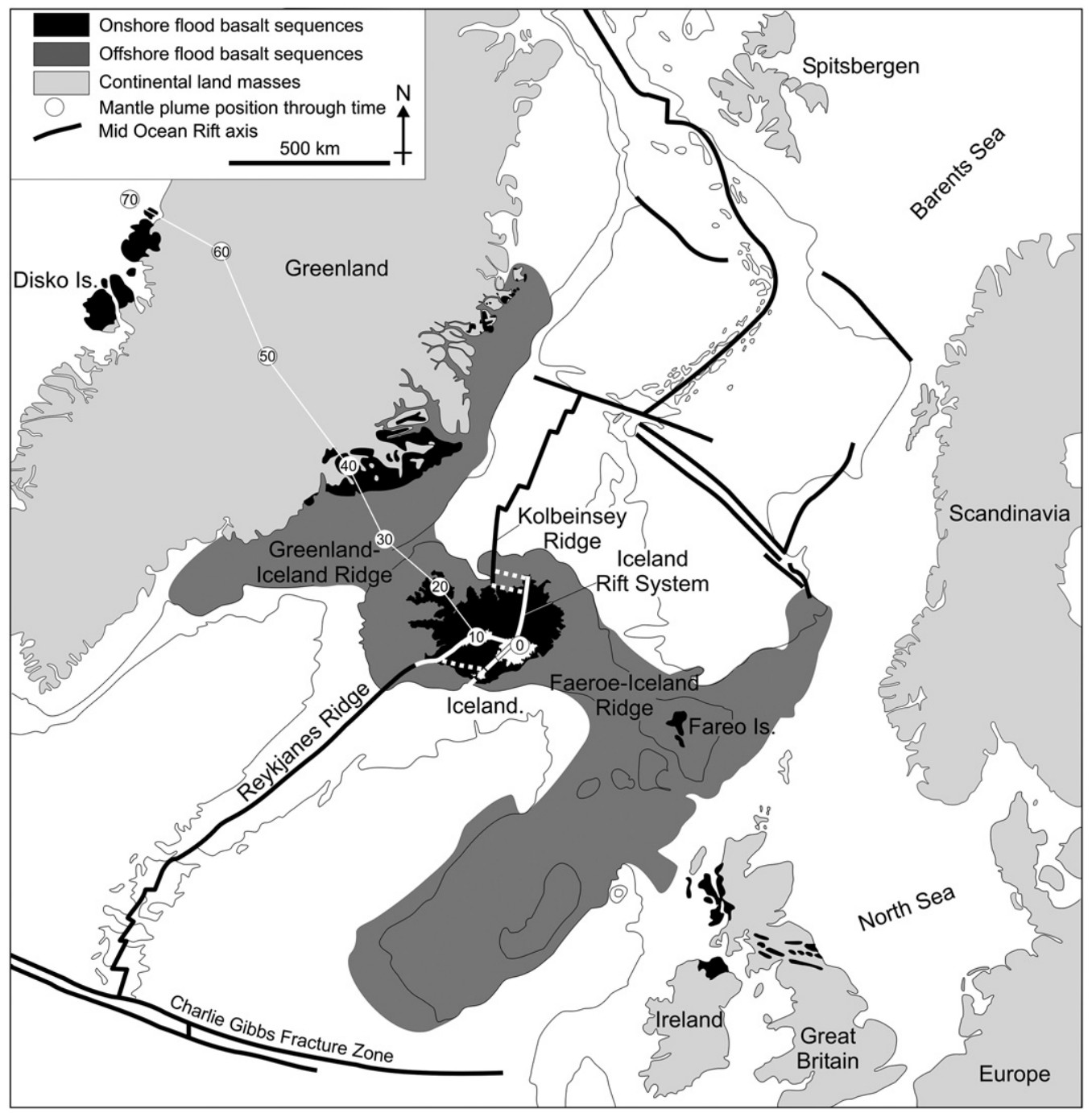

Fig. 1. Iceland is an elevated plateau in the middle of the North Atlantic, situated at the junction between the Reykjanes and Kolbeinsey Ridge segments. Also shown: the axis of the Mid-Atlantic Ridge (heavy solid line), the North Atlantic basalt plateau (black) and their submarine equivalents (dark grey). The line with the dots shows the position of the Iceland mantle plume from 65 million years to the present day. Modified after Saunders et al. (1997).

Gudmundsson, 2000). Of those the most prominent belt is the axial volcanic zone, the loci of active spreading and plate growth that follows the plate boundary across Iceland from Reykjanes in the southwest to Öxarfjörour in the north (Fig. 2). The axial zone is typified by tholeiitic magmatism and its core structures are the West (WVZ) and the North (NVZ) Volcanic Zones, which are joined by Mid-Iceland Belt (MIB) and linked to the Mid-Atlantic Ridge system by the Reykjanes Volcanic Zone (RVZ) in the south and the Tjörnes Fracture Zone (TFZ) in the North. The East Volcanic Zone (EVZ) is an axial rift in the making that eventually will take over from the West Volcanic Zone. It is dominated by tholeiitic magmatism in the northeast (Fig. 3a), whereas mildly alkalic magmatism characterizes the currently propagating southwest segment of the zone (e.g. Jakobsson, 1979a; Sæmundsson, 1979; Gudmundsson, 1995a). Its construction has taken place by southwest propagation of volcanism through pre-existing crust and at present it is the most volcanically active region in Iceland (Fig. 2). There are also two active intraplate volcanic belts of mildly alkalic magmatism in Iceland. The Öræfi Volcanic Belt situated to the east of the current plate margins, which may represent an embryonic rift (Thordarson and Höskuldsson, 2002). The Snæfellsnes Volcanic Belt in west Iceland, an old rift zone reactivated about $2 \mathrm{Ma}$ and is currently propagating to the east-southeast 


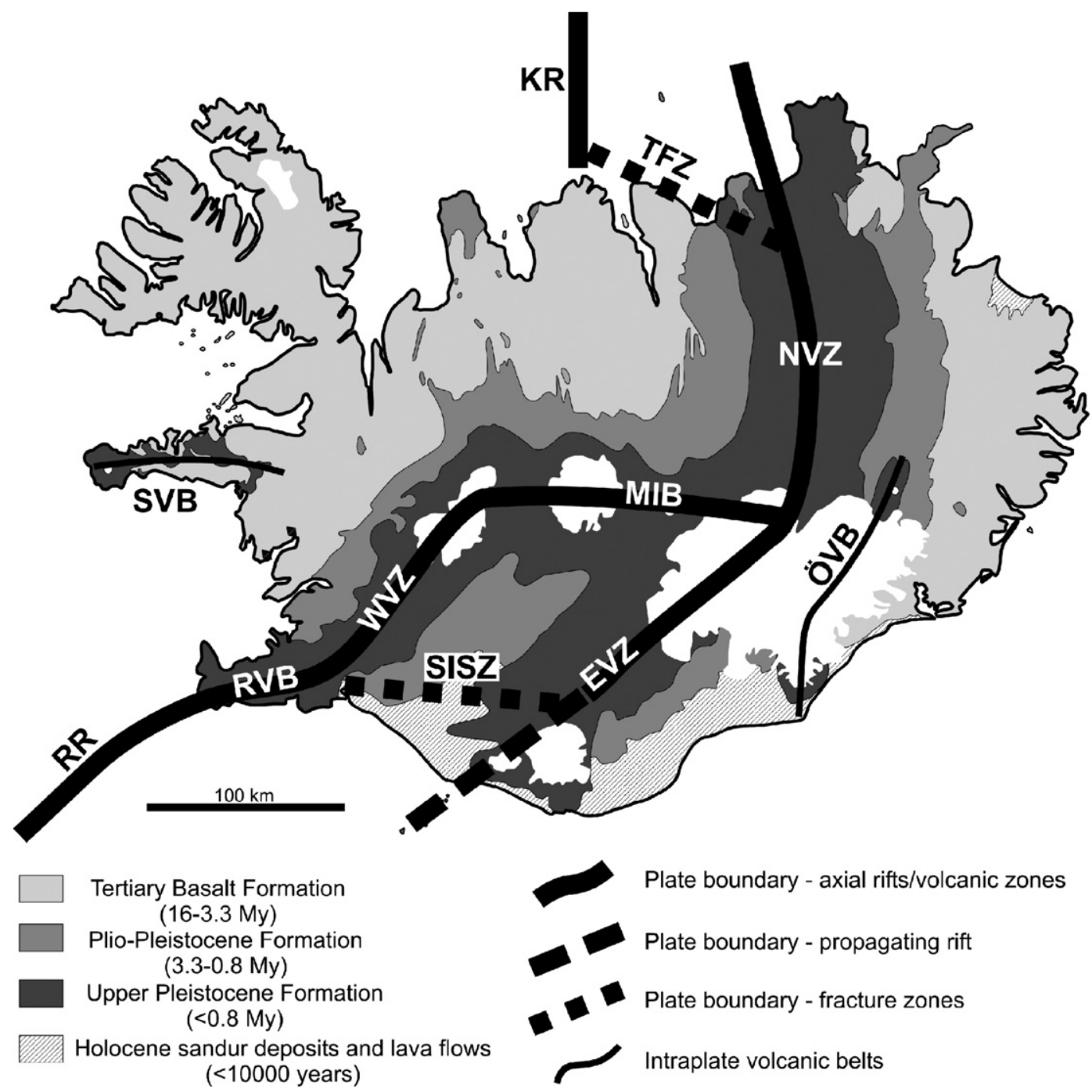

Fig. 2. The principal elements of the geology in Iceland, outlining the distribution of the major geological subdivisions, including the main fault structures and volcanic zones and belts. RR, Reykjanes Ridge; RVB, Reykjanes Volcanic Belt; SISZ, South Iceland Seismic Zone; WVZ, West Volcanic Zone; MIB, Mid-Iceland Belt; EVZ, East Volcanic Zone; NVZ, North Volcanic Zone; TFZ, Tjörnes Fracture Zone; KR, Kolbeinsey Ridge; ÖVB, Öræfi Volcanic Belt; SVB, Snæfellsnes Volcanic Belt. Modified from Thordarson and Höskuldsson (2002).

(e.g. Gudmundsson, 2000). Collectively, the regions of active volcanism cover $\sim 30,000 \mathrm{~km}^{3}$ or about one third of Iceland.

\subsection{Volcanic structures in Iceland}

The volcanic system can be viewed as the principal geological structure in Iceland (Fig. 3). It is characterized by conspicuous volcanotectonic architecture that features a fissure (dyke) swarm or a central volcano or both and has a typical lifetime of 0.5-1.5 million years (e.g. Jakobsson et al., 1978; Jakobsson, 1979a; Sæmundsson, 1978, 1979). The fissure swarms of each system are elongate structures that normally are aligned sub-parallel to the axis of the hosting volcanic zone. The central volcano, when present, is the focal point of eruptive activity and typically the largest edifice within each system (Fig. 3). The first to identify the clustering of volcanic and tectonic surface structures that now are 


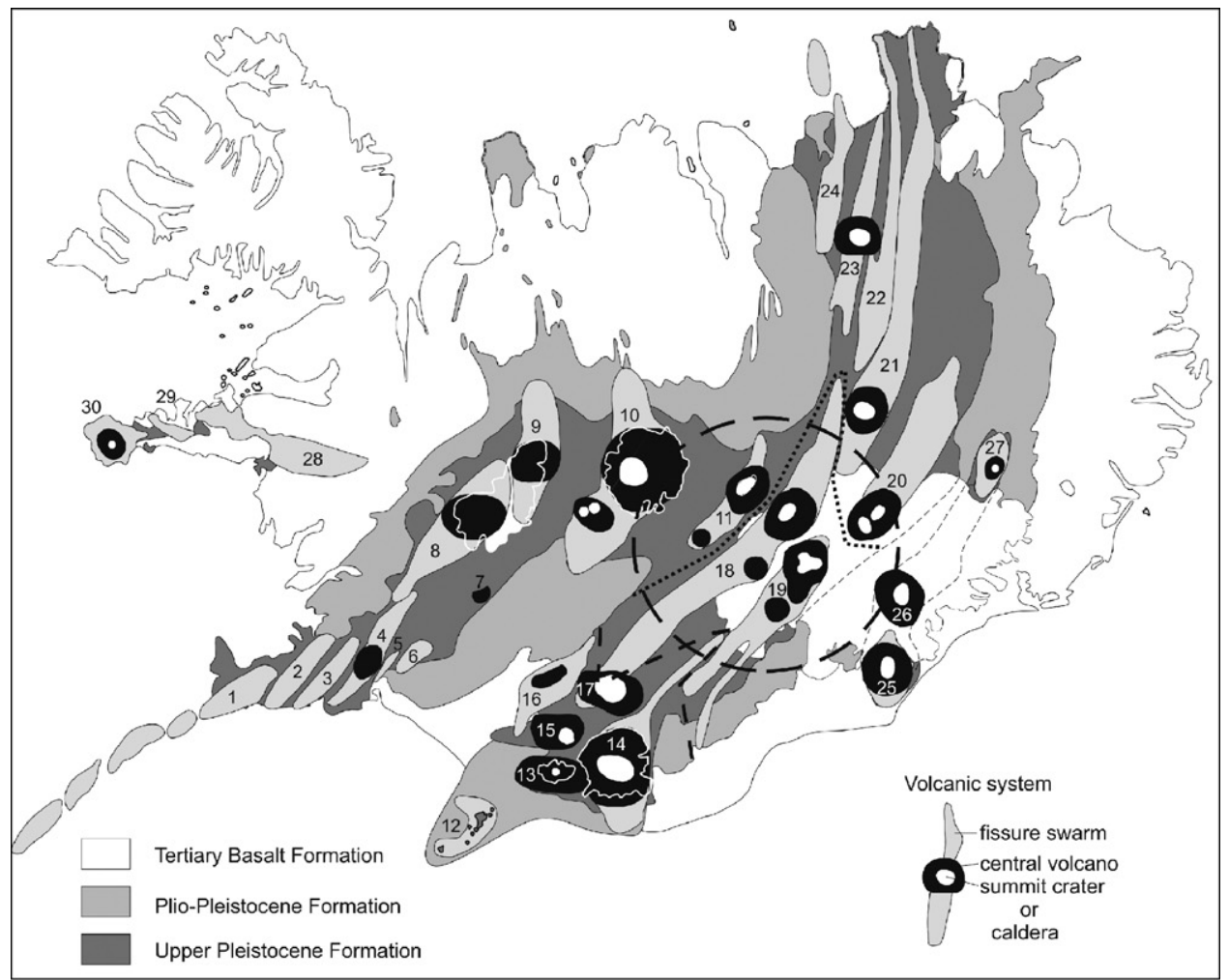

(a)
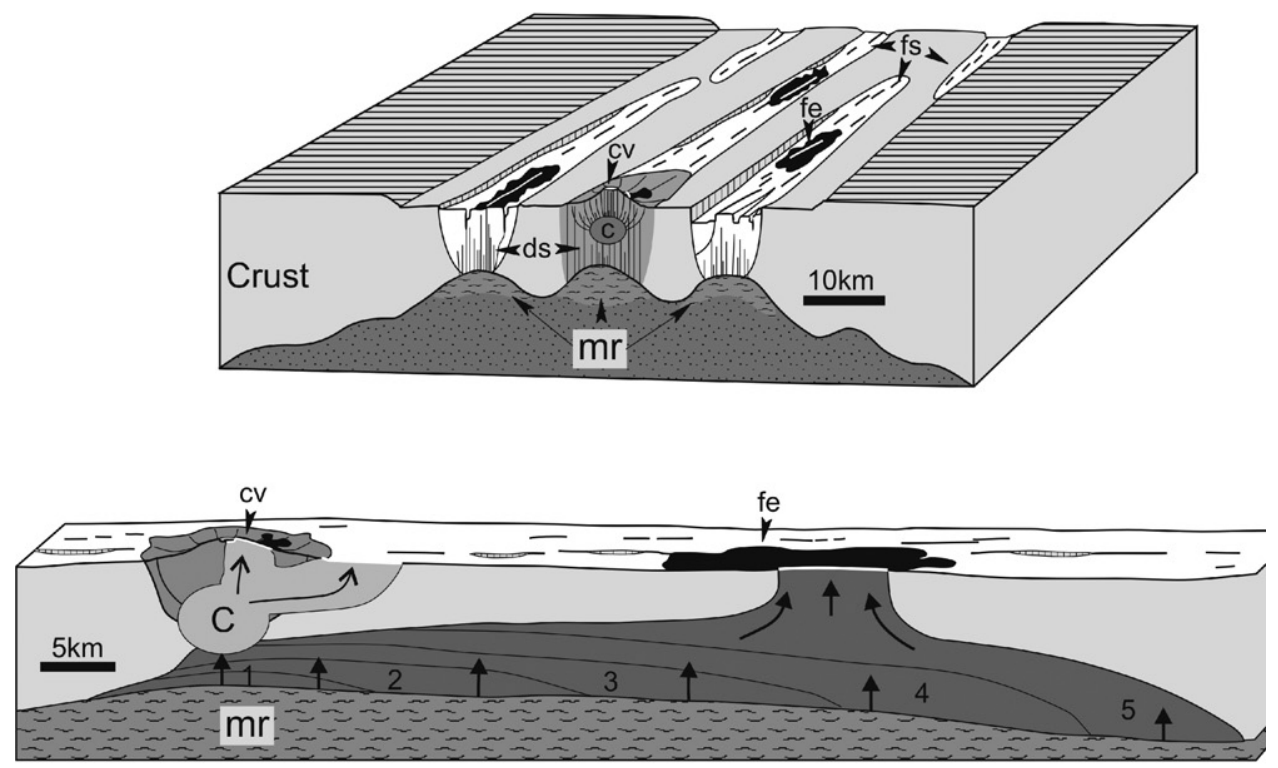

(b) 
used to define the volcanic systems was Bárdarson (1929) and he did so when mapping the geology of the Reykjanes peninsula. He referred to these clusters as "Vulkanbælter" (volcanic belts). Later studies, independently, reached the same conclusions regarding the overall volcanotectonic architecture in Iceland (e.g. Walker, 1959, 1963, 1964, 1975; Sæmundsson, 1974, 1978, 1979; Tryggvason, 1973; Jakobsson et al., 1978; Jakobsson, 1979a) and as such established the volcanic system as a fundamental structure in the volcanic successions (Jakobsson, 1979b; Gudmundsson, 1995b, 2000).

As illustrated in Fig. 3a, 30 volcanic systems are identified by Jóhannesson and Sæmundsson (1998) within the active volcanic regions; 3 within the RVZ, 6 in the WVZ, 2 in MIB, 5 in the NVZ, 8 in the EVZ and 3 in each of the intraplate volcanic belts. These systems are listed in Table 1 along with basic geometrical statistics. This tabulation shows that the size of individual systems ranges from $\sim 25$ to $2500 \mathrm{~km}^{2}$ and their length from 7 to $200 \mathrm{~km}$. According to this data, the Bárdarbunga-Veidivötn volcanic system $\left(\sim 2500 \mathrm{~km}^{2}\right)$ covers the largest area, followed by the Askja $\left(\sim 2300 \mathrm{~km}^{2}\right)$ and the Hofsjökull $\left(\sim 2200 \mathrm{~km}^{2}\right)$ systems. The smallest systems are that of Hrómundartindur $\left(\sim 24 \mathrm{~km}^{2}\right)$ and Geysir $\left(\sim 25 \mathrm{~km}^{2}\right)$. The two longest systems are Askja and Bárdarbunga-Veidivötn, $\sim 200$ and $\sim 190 \mathrm{~km}$, respectively.

Twenty of the 30 volcanic systems feature a fissure swarm (Jóhannesson and Sæmundsson, 1998). Of those 12 are well developed and mature swarms, 5 are of moderate maturity and 4 can be regarded as embryonic (Table 1). The mature and moderately mature fissure swarms are distinct narrow and elongated strips (5-20 km wide and 50-200 km long) with high density of tensional cracks, normal faults and volcanic fissures, whereas embryonic swarms feature one or a few discrete volcanic fissures.

Twenty-three central volcanoes crown 19 volcanic systems. Four systems, Hofsjökull, Tungnafellsjökull, Bárdarbunga-Veidivötn and Grímsvötn, feature two central volcanoes (Fig. 3; Table 1). The map by Jóhannesson and Sæmundsson (1998) shows the remaining systems with domains containing high-temperature geothermal fields. These domains are thought to indicate the presence of a shallow crustal magma holding chamber and thus may represent central volcanoes that perhaps are in their earliest growth stage.

Events on the volcanic systems within the axial volcanic zones are intimately linked to the plate movements. The spreading and subsequent rifting of the crust that takes place at the plate boundary is not a continuous process, in either time or space. It occurs in distinct rifting episodes that most commonly are confined to a single volcanic system at any one time, although near-concurrent activity on two or more system is know to have happened (e.g. Jónsson, 1983; Einarsson and Jóhannesson, 1989; Thordarson and Self, 1993; Sigurgeirsson, 1992, 1995; Larsen et al., 1998). Normally the whole system is activated in these episodes that can last for several years to decades and the tradition is to refer to such events as 'Fires' (e.g. the Krafla Fires). These episodes are characterized by recurring earthquake swarms and volcanic eruptions within the central volcano and on the fissure swarm.

Two somewhat contrasting models have been proposed for the subsurface structure of the volcanic system and behaviour of the magma plumbing system during major rifting episodes:

(a) One where magma replenishment and pressurization of a shallow crustal chamber and subsequent injection of lateral dykes into the fissure swarm is viewed as the driving mechanism of rifting on the volcanic system (e.g. Sigurdsson and Sparks, 1978; Björnsson et al., 1979; Brandsdóttir and Einarsson, 1979; Sæmundsson, 1979; Björnsson, 1985; Einarsson, 1991).

Fig. 3. (a) Distribution of active volcanic systems among volcanic zones and belts in Iceland as depicted by Jóhannesson and Sæmundsson (1998). Reykjanes Volcanic Zone: (1) Reykjanes-Svartsengi, (2) Krýsuvík, (3) Brennisteinsfjöll; West Volcanic Zone: (4) Hengill, (5) Hrómundartindur, (6) Grímsnes, (7) Geysir, (8) Prestahnjúkur, (9) Langjökull; Mid-Iceland Belt: (10) Hofsjökull, (11) Tungnafellsjökull; East Volcanic Zone: (12) Vestmannaeyjar, (13) Eyjafjallajökull, (14) Katla, (15) Tindfjöll, (16) Hekla-Vatnafjöll, (17) Torfajökull, (18) Bárðarbunga-Veiðivötn, (19) Grímsvötn; North Volcanic Zone: (20) Kverkfjöll, (21) Askja, (22) Fremrinámur, (23) Krafla, (24) Peistareykir; Öræfajökul Volcanic Belt: (25) Öræfajökull, (26) Esjufjöll, (27) Snæfell; Snæfellsnes Volcanic Belt: (28) Ljósufjöll, (29) Helgrindur, (30) Snæfellsjökull. The large open circle indicates the approximate centre of the Iceland mantle plume/anomaly as depicted by Wolfe et al. (1997). Dotted line shows the northern limits of the East Volcanic Zone, whereas the hachured line indicates the boundary between the active and propagating rift segments of the zone. (b) Key structures of volcanic systems. Upper panel shows the main structural elements of a volcanic system. mr, magma reservoir; c, crustal magma chamber; ds, dyke swarm; cv, central volcano; fs, fissure swarm; fe, fissure eruption. Lower panel depicts the two modes of dyke injection predicted by model (a) and model (b) (see text for details). The numbers indicate the growth sequence of the vertical dyke from a magma reservoir. 
Table 1

Volcanic systems in Iceland

\begin{tabular}{|c|c|c|c|c|c|c|c|c|c|}
\hline & $\begin{array}{l}\text { Volcanic } \\
\text { zone }\end{array}$ & Name & $\begin{array}{l}\text { Max. elev. }{ }^{\mathrm{a}} \\
\text { (m.a.s.l.) }\end{array}$ & $\begin{array}{l}\text { Length } \\
(\mathrm{km})\end{array}$ & $\begin{array}{l}\text { Width } \\
(\mathrm{km})\end{array}$ & $\begin{array}{l}\text { Area } \\
\left(\mathrm{km}^{2}\right)\end{array}$ & $\begin{array}{l}\text { Fissure } \\
\text { swarm }^{b}\end{array}$ & $\begin{array}{l}\text { Central } \\
\text { volcano }^{c}\end{array}$ & Name of central volcano \\
\hline 1 & RVZ & Reykjanes/Svartsengi & 163 & 58 & 13 & 350 & $\mathrm{xxx}$ & $\mathrm{d}$ & \\
\hline 2 & RVZ & Krýsuvík & 393 & 55 & 13 & 300 & $\mathrm{xxx}$ & d & \\
\hline 3 & RVZ & Brennisteinsfjöll & 621 & 45 & 10 & 280 & $\mathrm{xxx}$ & d & \\
\hline 4 & WVZ & Hengill & 803 & 60 & 9 & 370 & $\mathrm{xxx}$ & $\mathrm{cv}$ & Hengill \\
\hline 5 & WVZ & Hrómundartindur & 283 & 7 & 8 & 25 & & d & \\
\hline 6 & WVZ & Grímsnes & 214 & 15 & 8 & 100 & $\mathrm{xx}$ & d & \\
\hline 7 & WVZ & Geysir ${ }^{c}$ & 600 & 7 & 7 & 25 & & d & \\
\hline 8 & WVZ & Prestahnjúkur & 1400 & 80 & 27 & 950 & $\mathrm{xxx}$ & $\mathrm{cv}$ & Prestahnjúkur \\
\hline 9 & WVZ & Hveravellir & 1000 & 60 & 18 & 720 & $\mathrm{xx}$ & $\mathrm{cv}$ & Hveravellir \\
\hline 10 & MIB & Hofsjökull & 1800 & 95 & 38 & 2200 & $\mathrm{xxx}$ & $\mathrm{cv}$ & Hofsjökull/Kerlingarfjöll \\
\hline 11 & MIB & Tungnafellsjökull & 1520 & 55 & 15 & 530 & $\mathrm{xx}$ & $\mathrm{cv}$ & Tungnafellsjökull/Hágöngur \\
\hline 12 & EVZ & Vestmannaeyjar & 283 & 28 & 25 & $<480$ & $\mathrm{xx}$ & d & \\
\hline 13 & EVZ & Eyjafjallajökull & 1666 & 30 & 14 & 300 & & $\mathrm{cv}$ & Eyjafjallajökull \\
\hline 14 & EVZ & Katla & 1480 & 110 & 30 & 1300 & $\mathrm{x}$ & $\mathrm{cv}$ & Mýrdalsjökull \\
\hline 15 & EVZ & Tindfjöll $^{\mathrm{c}}$ & 1462 & 20 & 14 & 230 & & $\mathrm{cv}$ & Tindfjöll \\
\hline 16 & EVZ & Hekla-Vatnafjöll & 1491 & 60 & 19 & 720 & $\mathrm{xx}$ & $\mathrm{cv}$ & Hekla \\
\hline 17 & EVZ & Torfajökull & 1278 & 50 & 20 & 900 & & $\mathrm{cv}$ & Torfajökull \\
\hline 18 & EVZ & Bárdarbunga-Veidivötn & 2009 & 190 & 28 & 2500 & $\mathrm{xxx}$ & $\mathrm{cv}$ & Bárdarbunga/Hamarinn \\
\hline 19 & EVZ & Grímsvötn & 1722 & 100 & 23 & 1350 & $\mathrm{x}$ & $\mathrm{cv}$ & Grímsvötn/Thórdarhyrna \\
\hline 20 & NVZ & Kverkfjöll & 1934 & 120 & 20 & 1600 & $\mathrm{xxx}$ & $\mathrm{cv}$ & Kverkfjöll \\
\hline 21 & NVZ & Askja & 1510 & 200 & 20 & 2300 & $\mathrm{xxx}$ & $\mathrm{cv}$ & Askja \\
\hline 22 & NVZ & Fremrinámur & 800 & 150 & 15 & 1200 & $\mathrm{xxx}$ & d & \\
\hline 23 & NVZ & Krafla & 818 & 100 & 19 & 900 & $\mathrm{xxx}$ & $\mathrm{cv}$ & Krafla \\
\hline 24 & NVZ & Theistareykir & 600 & 90 & 9 & 650 & $\mathrm{xxx}$ & d & \\
\hline 25 & ÖVB & Öræfajökull & 2110 & 20 & 21 & 250 & & $\mathrm{cv}$ & Öræfajökull \\
\hline 26 & ÖVB & Esjufjöll $^{\mathrm{d}}$ & 1760 & 25 & 21 & 400 & & $\mathrm{cv}$ & Snæhetta \\
\hline 27 & ÖVB & Snæfell $^{\mathrm{d}}$ & 1833 & 20 & 11 & 170 & & $\mathrm{cv}$ & Snæfell \\
\hline 28 & SVB & Ljósufjöll & 1063 & 80 & 15 & 720 & $\mathrm{x}$ & d & \\
\hline 29 & SVB & Helgrindur (Lýsuskard) & 647 & 30 & 8 & 220 & $\mathrm{x}$ & d & \\
\hline 30 & SVB & Snæfellsjökull & 1446 & 30 & 20 & 470 & & $\mathrm{cv}$ & Snæfellsjökull \\
\hline
\end{tabular}

Based on Jóhannesson and Sæmundsson (1998).

${ }^{a}$ Maximum elevation above sea level.

b $\mathrm{xxx}$, mature; xx, moderate maturity; x, embryonic.

c cv, central volcano; d, domain.

${ }^{\mathrm{d}}$ No verified eruption of Holocene age.

(b) Another where rifting episodes on volcanic systems are driven by the magma pressurization in large and elongate reservoirs at the base of the crust ( $>20 \mathrm{~km}$ depth) and subsequent injection of subvertical dykes into the upper crust (e.g. Gudmundsson, 1987a, 1995b, 2000).

The first and earlier established model is based on detailed deformation and seismic studies at the Krafla volcanic system during the 1975-1985 rifting episode (i.e. the Krafla Fires, e.g. Einarsson, 1991 and references therein). In this model, a deep-rooted central plumbing system beneath the central volcanoes intermittently feeds magma to the shallow crustal reservoir situated at $2-6 \mathrm{~km}$ depth, which in turn inflates. Rifting and lateral dyke injections into the fissure swarm occur when the inflation has pressurized the chamber such that the magma overpressure exceeds the tensile strength of the crust (Fig. 3b).

In the other model, which was first proposed by Gudmundsson (1987a, 1995b) and based on systematic studies of volcanotectonic structures in Iceland, the fissure swarm and the central volcano are surface expressions of two different types of subsurface magma holding systems (Fig. 3b). The fissure swarms are the surface expressions of elongated deep-seated magma reservoirs, which are situated at the base of the crust ( $>20 \mathrm{~km} \mathrm{depth}$ ). The central volcano is a surface manifestation of shallow crustal magma chambers which are located at $2-6 \mathrm{~km}$ depth. Here the view is that rifting is a response to replenishment and pressurization of magma within the deep-seated reservoir, resulting in vertical dyke injections that mobilize the whole system, including the crustal magma chamber (Fig. 3b). 


\section{Volcanic activity: general considerations}

\subsection{Volcano types and forms}

The term volcano encompasses a wide range of structures that are constructed around the vent(s) by the volcanic activity, whether they are formed by single (monogenetic) or multiple (polygenetic) eruptions (Macdonald, 1972; Cas and Wright, 1987; Francis and Oppenheimer, 2004). The overall architecture of a volcano is primarily determined by the type of magma erupted, the habitual eruption behaviour, the shape of the vent system and the environmental setting (i.e. subaerial, subglacial, submarine). Consequently, volcanoes display a wide spectrum of forms, ranging from a crack in the ground to the majestic stratovolcanoes. This variability in form and shape is showcased exceptionally well in Iceland, because it displays all known volcano types on Earth with the exception of diatremes (Thorarinsson and Sæmundsson, 1979; Thorarinsson, 1981).

It is not a straightforward exercise to determine how many active volcanoes there are in Iceland. It is easy to count the number of central volcanoes that have erupted time after time during the Holocene, which are 17 in total (Table 1). However, the difficulty arises when we assess the status of monogenetic volcanoes, because by definition these volcanoes are extinct, although the region where they are located is still volcanically active. This problem is circumvented by considering a monogenetic volcano to be active if it is located within a volcanic system that is still active (i.e. produced eruptions in the Holocene).

\subsubsection{Central volcanoes}

Icelandic central volcanoes are constructed by repeated eruptions from a central vent system that is maintained by a long-lived plumbing system. The recurring eruptions occur on circular summit vents or ring fractures within the summit caldera or on short, often radial, fissures on the outer flanks of the volcano (e.g. Gudmundsson, 2000). Published studies of Tertiary-age central volcanoes show that their construction was dominated by effusion of basaltic lavas, with small but significant contribution from eruptions of intermediate and silicic magma (e.g. Walker, 1959, 1963; Carmichael, 1964; Blake, 1970). Volcaniclastic deposits make up a small proportion of the succession, typically around 3-6\%, but values up to $20 \%$ are known. Thus, the overall morphometry and lithofacies associations of these Tertiary centres bear strongest resemblance to the Hawaiian shield volcanoes, such as Kilauea and Kohala on the Big Island of Hawaii (Macdonald et al., 1970; Walker, 1990; Moore and Clauge, 1992). However, the proportions of intermediate to silicic rocks are generally higher in the Icelandic centres (e.g. Carmichael, 1964; Blake, 1970). On the other hand, the construction of modern central volcanoes in Iceland has been influenced by ice-volcano interactions, although to variable degree. Consequently, they are characterized by a succession of alternating lava flows and volcaniclastic deposits and thus are composite volcanoes by definition (Macdonald, 1972). Ten of the presently active central volcanoes (i.e. Grímsvötn, Bárdarbunga, Mýrdalsjökull, Eyjafjallajökull, Hengill, Tindfjöll, Hofsjökull, Tungnafellsjökull, Askja and Kverkfjöll) have a foundation that is largely constructed by subglacial eruptions (e.g. Sæmundsson, 1967, 1995; Jakobsson, 1979a; Sigvaldason, 2002; Loughlin, 2002). Their form is irregular and variable, but characterized by moderately sloping flanks $\left(4-8^{\circ}\right)$ and broad summit regions that are typically capped by $7-15 \mathrm{~km}$ wide nested caldera complexes (Fig. $4 \mathrm{a}$ ). None of these volcanoes conform to the criteria set up for classification of either stratovolcanoes or shield volcanoes (e.g. Cas and Wright, 1987; Francis and Oppenheimer, 2004), although Eyjafjallajökull volcano does show a close morphological resemblance to the polygenetic Hawaiian shields (Fig. 4b; see also Fig. 11-8 in Macdonald, 1972). Five Icelandic central volcanoes (i.e. Snæfellsjökull, Kerlingarfjöll, Öræfajökull, Snæfell and Hekla) match the accepted criteria for the classification of stratovolcanoes; a composite cone with 15-33 ${ }^{\circ}$ slopes (e.g. Pike and Clow, 1981). The Icelandic stratovolcanoes are generally capped by a summit crater or a small caldera that is often lined with lava domes along the rim slopes (Fig. 4c). The infamous Hekla volcano is an exception because it is a ridge-shaped stratovolcano. When viewed from the southwest (or northeast), the volcano exhibits a classical cone form (Fig. 4d), but if it is viewed from the northwest (or southeast) the form is similar to that of a boat with its keel turned up (Fig. 4e). The ridge-shape form of Hekla is the consequence of repeated eruptions that occur along a $\sim 5 \mathrm{~km}$ long fissure extending from the southwest shoulder, across the summit, and onto the northwest shoulder of the volcano. Two of the central volcanoes in Iceland, namely Torfajökull and Krafla, are characterized by very gently sloping $\left(<4^{\circ}\right)$ flanks around large, $10-18 \mathrm{~km}$ wide calderas that are largely filled up by eruption products post-dating the caldera collapse. The profiles of these volcanoes are broadly similar to continental andesite-rhyolite caldera volcanoes or multivent complexes as defined by Walker (1984) and especially applicable to Torfajökull (Fig. 5). Knowledge of the structure and 

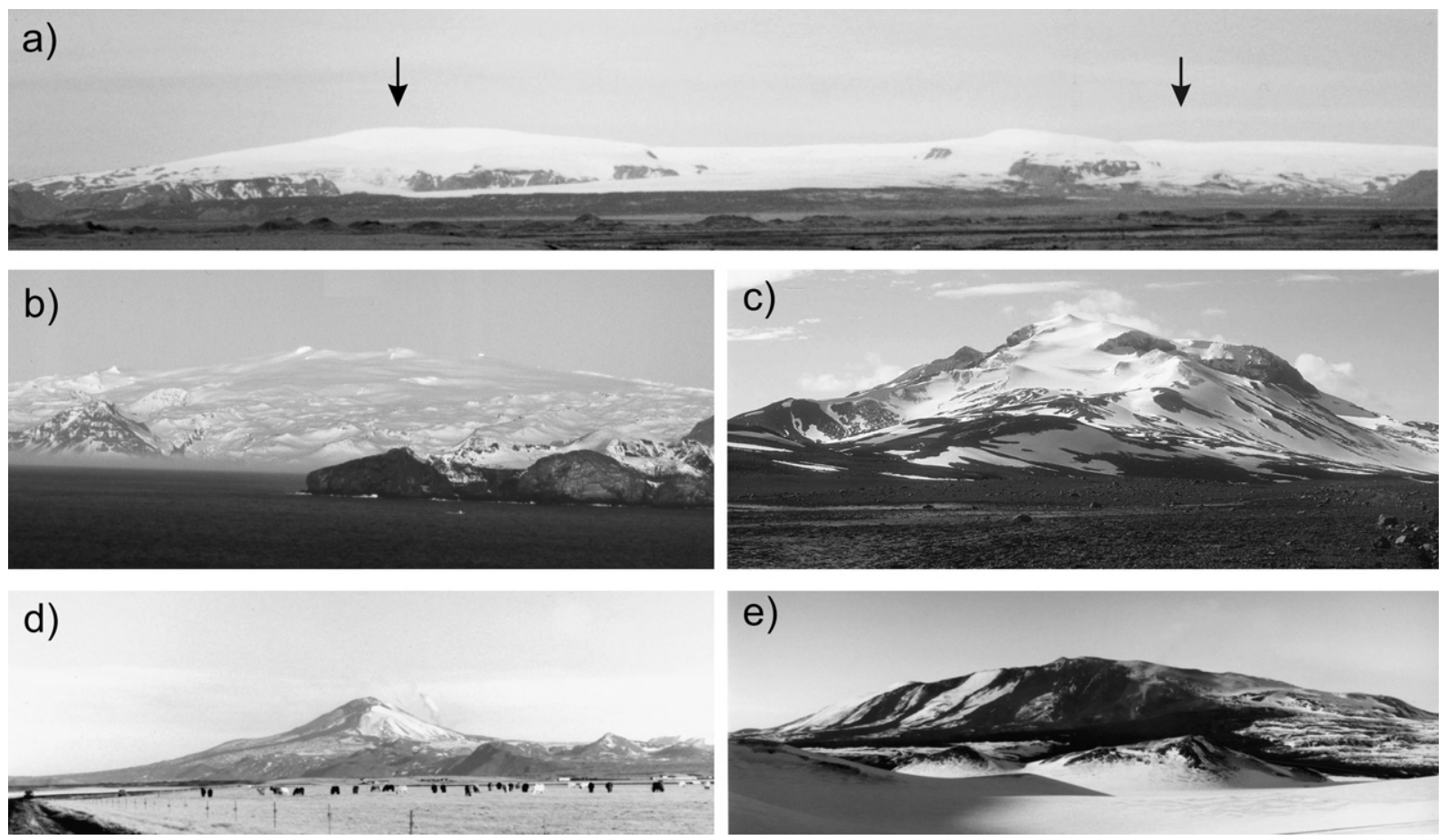

Fig. 4. Central volcanoes: (a) Mýrdalsjökull central volcano. Arrows point to the south (left) and north (right) caldera rims; note the relatively low $\left(\sim 5-6^{\circ}\right)$ slope of the flanks on either side. (b) The shield-like volcano of Eyjafjallajökull (photo Á. Höskuldsson). (c) The stratovolcano Snæfell (photo Á. Höskuldsson). (d and e) Hekla volcano viewed from the southwest and the east (see text for details).

architecture of remaining central volcanoes listed in Table 1 is fragmentary and therefore they are not considered further here.

\subsubsection{Basalt volcanoes}

The late Professor Sigurdur Thórarinsson (e.g. Thorarinsson, 1981) proposed a classification scheme for Icelandic volcanoes that is based on the vent form and the nature of vent products. In this scheme, the geometry of the vent system is the distinguishing parameter, where the vent systems are categorized as a linear or point source (Fig. 6). The former category includes vent systems demarked as fissures, whereas the latter represents circular vent systems and those that initially were short fissures but activity was then rapidly reduced to a single vent. Linear vent systems in Iceland range in length from a few hundred meters to $>75 \mathrm{~km}$, whereas the circular types have crater diameters $<1.2 \mathrm{~km}$ (range, $10 \mathrm{~s}$ to $1100 \mathrm{~m}$ ). Second order parameters are the types of deposits (i.e. lava, clastogenic lava, spatter, scoria or ash) that characterize the vent accumulations or ramparts. This scheme is particularly useful for classification of monogenetic basalt volcanoes that characterize the fissure swarms in Iceland and is adapted here with minor modifications (Table 2).

In this scheme, subaerial monogenetic volcanoes produced by magmatic eruptions are represented by single cones in case of circular vents or as cone rows when the vent system is linear. The monogenetic circular vent-type volcanoes include lava shields, spatter rings, and scoria cones and are generally produced by purely effusive to weakly fountaining eruptions. Spatter ring and scoria cone volcanoes, such as Eldborg at Mýrar and Eldfell at Heimaey (Fig. 6a and b), are exactly what the terms imply, a steep-sided ring of spatter and conical pile of scoria rising above a small lava flow field. Typically, they are formed by relatively short-lived (days to months) and small $\left(\leq 0.1 \mathrm{~km}^{3}\right)$ to medium $\left(0.1-1 \mathrm{~km}^{3}\right)$ volume eruptions. The large-volume $\left(>1 \mathrm{~km}^{3}\right)$ lava shields, such as Skjaldbreidur (Fig. 6c), are often remarkably symmetrical volcanoes, where a lava cone with summit crater and gently sloping $\left(3-10^{\circ}\right)$ outer flanks is circumscribed by a lava apron with surface slope of $0.5-2^{\circ}$ (e.g. Rossi, 1996). These shields are thought to be produced by a long-lived (years to decades) flood lava eruptions that are fed by sustained lava lakes residing in the summit vent (Table 2). It should be noted that smaller volume eruptions have also produced lava shields as exemplified by the effusive phase 
Table 2

Classification of basaltic volcanoes in Iceland

\begin{tabular}{|c|c|c|c|c|c|}
\hline \multicolumn{2}{|l|}{ Eruption characteristics } & \multirow{2}{*}{$\begin{array}{l}\text { Circular (central vent or } \\
\text { short fissure) }\end{array}$} & \multirow[t]{2}{*}{ Examples } & \multirow[t]{2}{*}{ Linear (long fissure) } & \multirow[t]{2}{*}{ Examples } \\
\hline Environment & Eruption type & & & & \\
\hline \multirow{3}{*}{ Subaerial magmatic } & $\begin{array}{l}\text { Effusive-less explosive } \\
\text { (flood lava) }\end{array}$ & Lava shield & $\begin{array}{l}\text { Skjaldbreidur, } \\
\text { Kollóttadyngja }\end{array}$ & Mixed cone row & Laki, Eldgjá \\
\hline & Effusive & Spatter ring (eldborg) & $\begin{array}{l}\text { Eldborg at Mýrar, } \\
\text { Búrfell in Heidmörk }\end{array}$ & Spatter cone row & $\begin{array}{l}\text { Tröllagígar, } \\
\text { Threngslaborgir }\end{array}$ \\
\hline & $\begin{array}{l}\text { Effusive-explosive } \\
\text { Explosive }\end{array}$ & Scoria cone & Eldfell, Grábrók & $\begin{array}{l}\text { Scoria cone row } \\
\text { Volcanigenic chasms }\end{array}$ & $\begin{array}{l}\text { Vikraborgir, } \\
\text { Valagjá }\end{array}$ \\
\hline \multirow[t]{2}{*}{ Subaerial phreatomagmatic } & Explosive & $\begin{array}{l}\text { Tephra (tuff) cone, } \\
\text { tephra (tuff) ring }\end{array}$ & Hrossaborg, Hverfjall? & $\begin{array}{l}\text { Tephra (tuff) cone } \\
\text { row, tephra (tuff) ring } \\
\text { row }\end{array}$ & Vatnaöldur, Veidivötn ${ }^{\mathrm{a}}$ \\
\hline & & Maar & Grænavatn, Víti & Maar crater row & $?$ \\
\hline \multirow{3}{*}{ Subglacial and submarine } & Effusive & Pillow lava cone & $?$ & Pillow lava ridge & Kverkfjallarani \\
\hline & Effusive-explosive & Móberg cone seamount & Keilir Jólnir & $\begin{array}{l}\text { Móberg ridge or } \\
\text { submarine ridge }\end{array}$ & $\begin{array}{l}\text { Sveifluhals, } \\
\text { Eldeyjarbodi }\end{array}$ \\
\hline & Effusive-explosive-effusive & Table mountain & Herdubreid & $\begin{array}{l}\text { Table mountain } \\
\text { (ridge-like) }\end{array}$ & Bláfjall \\
\hline
\end{tabular}

Modified from Thorarinsson (1981). ?: no examples are known

a Svartikrókur segment. 


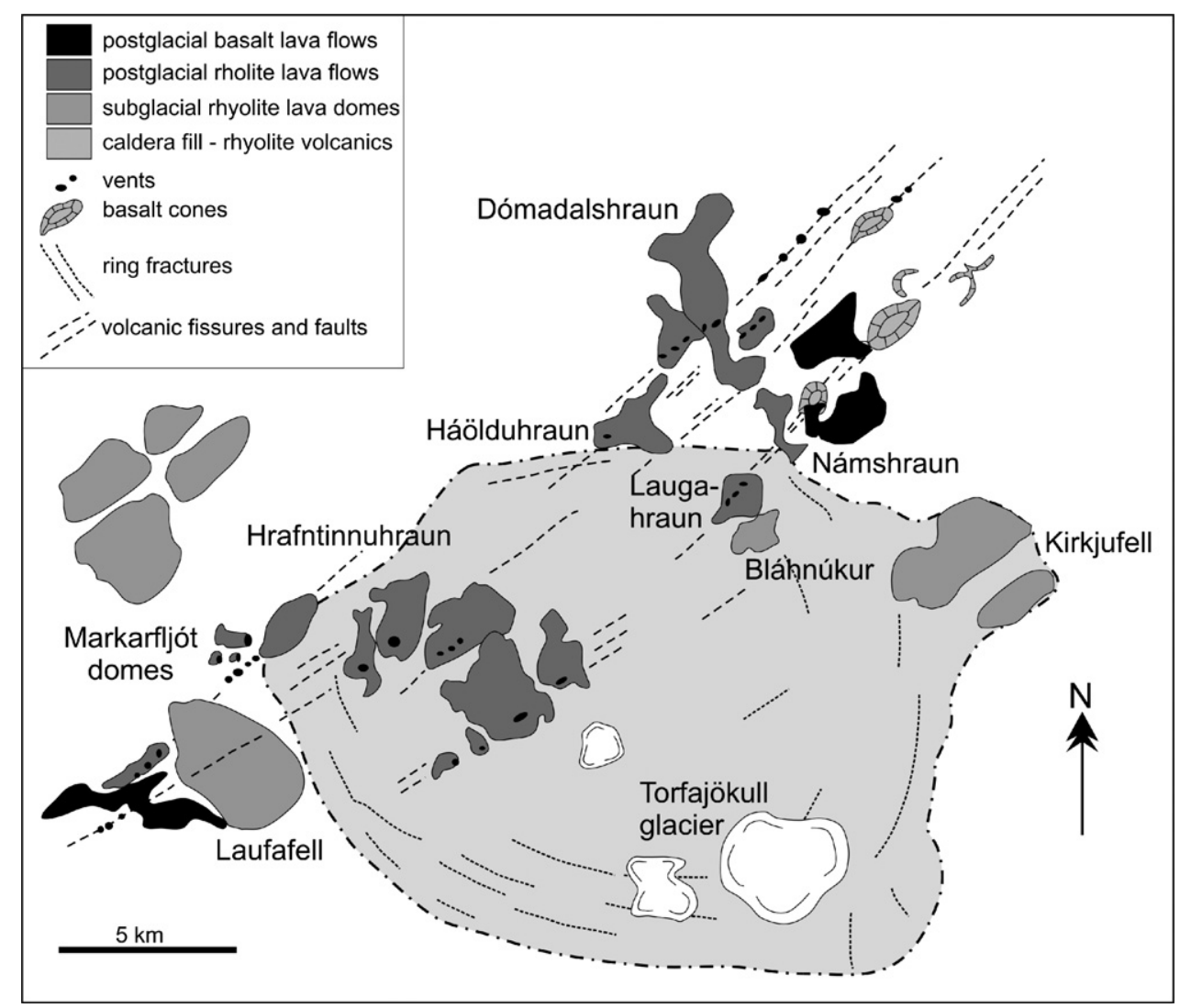

Fig. 5. Simplified geological map of the Torfajökull volcano. Modified from Macdonald et al. (1990).

of the 1963-1967 Surtsey eruption (Thordarson, 2000) and early Holocene picritic shields of the Reykjanes peninsula (e.g. Jónsson, 1978; Jakobsson et al., 1978).

Magmatic linear-type volcanoes or volcanic fissures are the trademark of Icelandic volcanism. They are demarked by a row of often tightly packed cratered cones, several meters to $>100 \mathrm{~m}$ high that delineate a volcanic fissure (e.g. Thorarinsson, 1981; Thordarson and Self, 1993). In some instances the cone rows define a single fissure segment, but most commonly the rows consist of multiple fissure segments in an en echelon arrangement. This group of basalt volcanoes includes spatter, scoria, and mixed cone rows, which are constructed by weakly to vigorously fountaining, lava-producing eruptions as well as volcanigenic chasms. Spatter and scoria cone rows are typically formed by small volume $\left(\leq 0.5 \mathrm{~km}^{3}\right)$ fissure eruptions. Spatter cone rows, such as the 1862-1864A.D. Tröllagígar on the Bárdarbunga-Veidivötn system, are common in Iceland, whereas scoria cone rows are rare and perhaps best represented by the 1961A.D. Vikraborgir row on the Askja volcanic system (Table 2). The most common type of linear volcanoes in Iceland is mixed cone rows (Thorarinsson, 1981). Mixed cone rows are complex vent systems that consists of spatter and scoria cones or hybrids thereof (Fig. 10d), but often also feature disparate vent structures such as "gjá" (chasm) and tuff cones as well as ramparts of clastogenic lava (Robson, 1957; Thorarinsson, 1981; Miller, 1989; Thordarson, 1991; Thordarson and Self, 1993). They are produced by short-lived (days to weeks) and long-lived (months to years) eruptions that traverse the size-spectrum of historical events in Iceland. The volume of erupted magma ranges from 0.01 to $20 \mathrm{~km}^{3}$. Mixed cone rows are typical of large-volume fissure eruptions, as is spectacularly illustrated by the vent systems of the 1783-1784A.D. Laki and 934-940A.D. Eldgja flood lava eruptions in South Iceland (Fig. 6d and e). These eruptions represent the two largest volcanic events in Iceland's history and the largest of its kind on Earth in the last 2000 years (e.g. Larsen, 2000; Thordarson et al., 2001, 2003a). However, it should be noted that not all large-volume fissure eruptions feature mixed cone rows, because the spatter cone rows of Threngslaborgir and Lúdentsborgir at Lake Mývatn were formed by an event that produced $2.5 \mathrm{~km}^{3}$ of erupted magma (e.g. Thorarinsson, 1951; Sæmundsson, 1991). Volcanigenic chasms are known to have formed in two pre-historical eruptions in Iceland; 

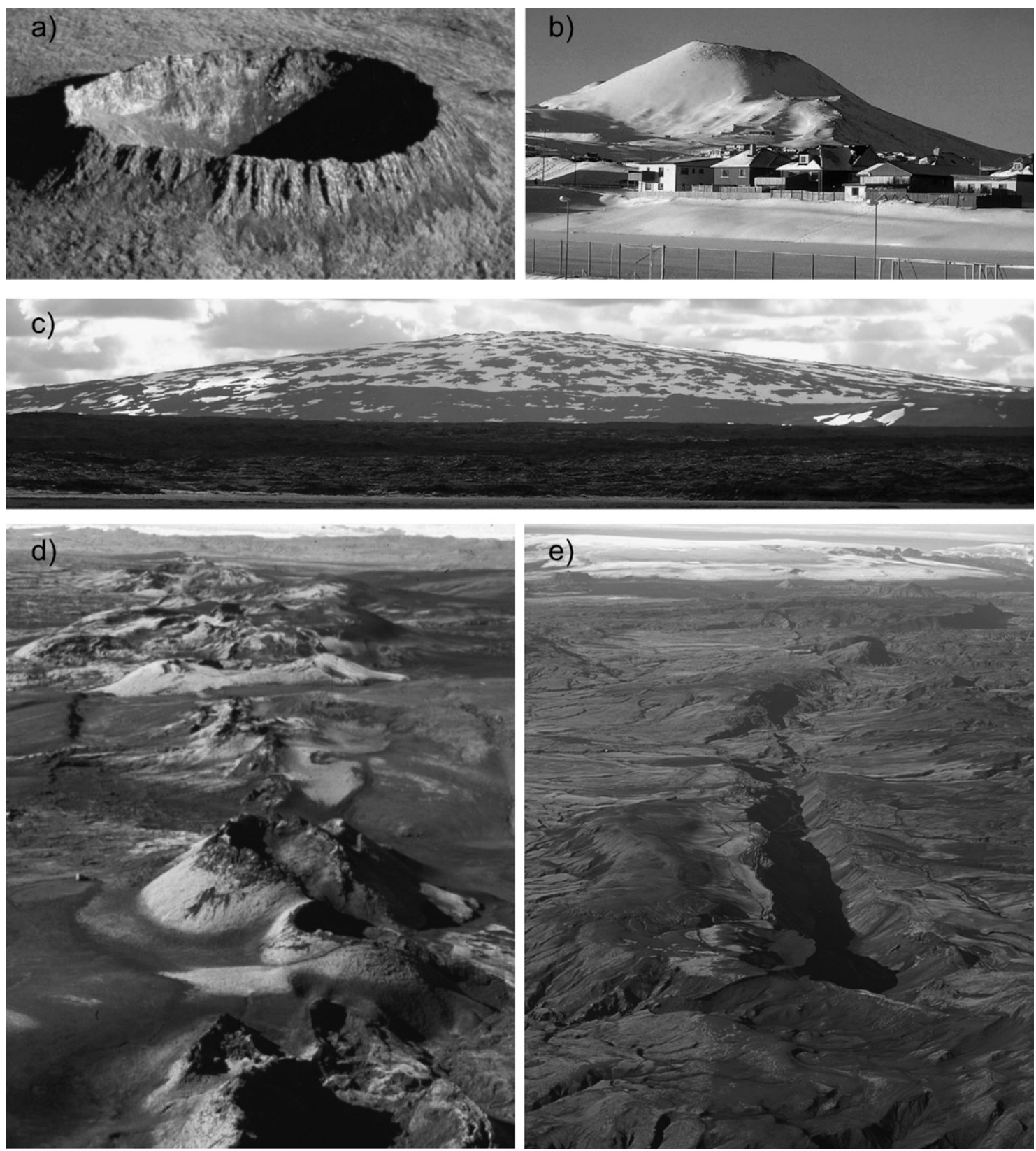

Fig. 6. (a) Spatter ring (Eldborg at Mýrar; photo R. Haraldsson), (b) Scoria cone (Eldfell at Heimaey, photo Á. Höskuldsson), (c) Lava shield (Kollóttadyngja, N-Iceland), (d) Mixed cone-row (Laki), and (e) Eldgjá Chasm (photo by O. Sigurdsson).

Valagjá on the Hekla volcanic system and Biskupsfellsgjá on the Kverkfjöll system (Thorarinsson, 1981; Karhunen, 1988). However, the most famous chasm in Iceland - Eldgjá proper, which is part of a $>75 \mathrm{~km}$ long 934-940A.D. Eldgjá vent system - is not a true volcanigenic chasm. Recent studies have shown that the volcanic fissure opened up in a pre-existing graben that is much older than the eruption (Miller, 1989). Although our knowledge of chasm-forming events in Iceland is still incomplete, they appear to begin with a short-lived phase of phreatomagmatic activity and the "gjá" formation, but then changes abruptly to magmatic eruption with vigorous fountaining activity producing meters to tens of meters thick vent successions consisting of clastogenic lava, spatter and scoria aligning the rims around the chasm. 

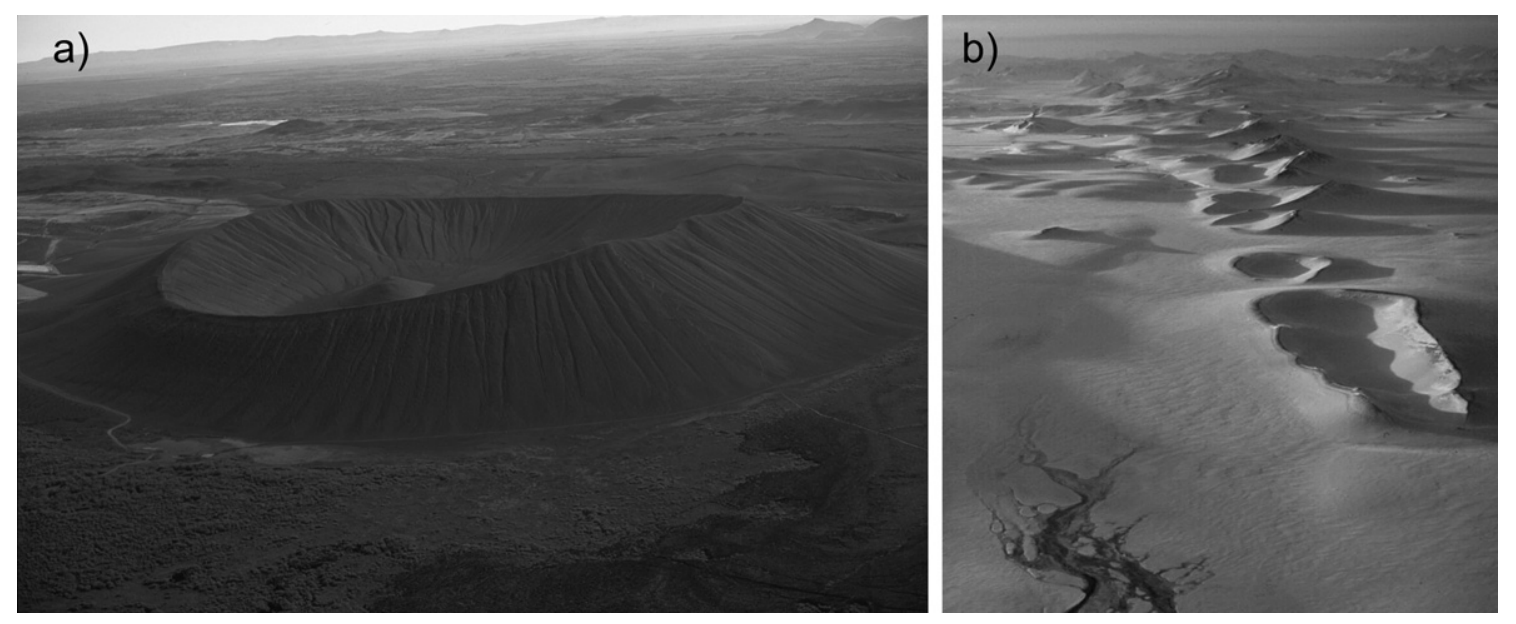

Fig. 7. (a) Hverfjall tuff cone at Mývatn and (b) Vatnaöldur tephra cone row (photos O. Sigurdsson).

By the same token, subaerial (and very shallow submarine) monogenetic volcanoes produced by phreatomagmatic eruptions are referred to as tephra or tuff cones and rings when constructed around a circular vent and as tephra or tuff cone rows when such vent structures delineate fissures (Fig. 7; Table 2; Heiken, 1971; Thorarinsson, 1981). The same terminology system applies to maar volcanoes, which are monogenetic phreatomagmatic or phreatic explosion craters filled with water (Lorentz, 1973).

Tuff cones represent some of the largest monogenetic volcanoes of the central vent-type in Iceland as demonstrated by the 2700 BP Hverfjall cone at Mývatn (e.g. Thorarinsson, 1952a, 1952b; Sæmundsson, 1991). Commonly, they are near-circular to horseshoe shaped cones with a broad crater (up to $1000 \mathrm{~m}$ in diameter) that is flanked by up to $150 \mathrm{~m}$ high cone walls consisting of multiple tephra beds that dip $15-35^{\circ}$ outwards from the crater (Fig. 7a). Tuff cone volcanoes are formed by small volume $\left(<0.5 \mathrm{~km}^{3}\right)$ eruptions characterized by intermittent explosive activity where expulsion of discrete tephra jets alternates with periods of continuous up-rush (e.g. Thorarinsson, 1965b, 1966, 1967b). Tephra cone rows, such as those produced by the 870A.D. Vatnaöldur and 1477A.D. Veidivötn, from spectacular 10 to $30 \mathrm{~km}$ long linear volcanoes that are delineated mainly by numerous tephra rings and cones, up to $1.8 \mathrm{~km}$ in diameter (Fig. 7b). They are formed by short-lived (days to weeks) phreatomagmatic eruptions of fairly large-volume (up to $1.5 \mathrm{~km}^{3} \mathrm{DRE}$; Larsen, 1984). Their formation involves development of somewhat special conditions within the volcanic zones as they have only formed in areas where ground water table is unusually high or large transient lakes have developed.

Subglacial and submarine monogenetic volcanoes are widespread in Iceland. They represent both the central ventand the linear-types that now are present as distinctive Quaternary landforms in the ice-free parts of the volcanic zones as well as structures within and beneath the current glaciers (e.g. Kjartansson, 1966a, 1966b; Jones, 1969, 1970; Björnsson and Einarsson, 1990; Smellie, 2000; Gudmundsson et al., 2002; Skilling, 2002). Two of the recent examples of such volcanoes are the vent structures of the 1963-1967A.D. Surtsey eruption in the Vestmannaeyjar archipelago and that of the 1996A.D. Gjálp eruption within Vatnajökull glacier (Thorarinsson, 1967b, 1967c; Gudmundsson et al., 1997). If water or ice pressure is sufficient pillow lavas are formed (Höskuldsson and Sparks, 1997) and pillow lava cones or ridges are produced if the eruption stops at this stage (Fig. 8a; Table 2). In case of ongoing eruption, the activity passes into an explosive phreatomagmatic phase and móberg cones or ridges are formed by eruptions that end at this stage (Fig. 8b). If the eruption continues further and the volcanic edifice becomes emergent, effusive activity resumes

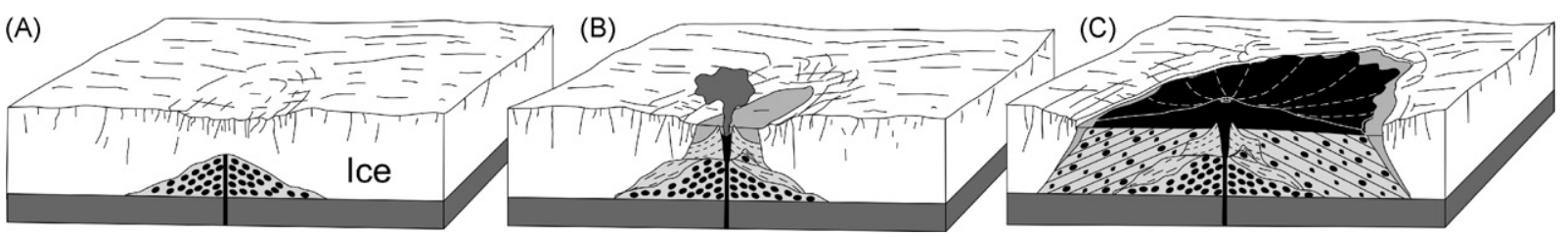

Fig. 8. Growth stages of a subglacial eruption: (a) pillow lava cone or ridge, (b) móberg cone or ridge forms, and (c) table mountain. After Jones (1969). 
producing lava deltas and subaerial flows (Fig. 8c). Eruptions that reached this stage form tuyas or table mountains (stapi in Icelandic), which are some of the most impressive volcanic structures in Iceland.

\subsection{Eruption styles and mechanisms}

Like elsewhere, Icelandic eruptions, regardless of their environmental setting, can feature a single style of activity, either purely explosive or effusive. However, many of them encompass both styles and such eruptions have been referred to as mixed eruptions (Thorarinsson, 1981; Thorarinsson and Sæmundsson, 1979). We maintain this terminology here with slight modifications. An eruption is effusive if the volume of lava comprises $\geq 95 \%$ of the bulk volume of erupted products. Similarly, an eruption is classified as explosive if the DRE-volume of the tephra is $\geq 95 \%$ of the total volume produced. Anything in-between is grouped as a mixed eruption. Moreover, volume figures for lava flows are taken here to correspond to dense rock equivalent (DRE) volumes and all tephra volume figures are given as DRE, unless otherwise noted.

Although volcanism in Iceland is typified by basaltic activity, its diversity in terms of the range in eruption types and styles is not surpassed by any other volcanic region on Earth as it spans the spectrum of effusive and explosive eruptions (Thorarinsson, 1981; Thorarinsson and Sæmundsson, 1979). This is very well exemplified by the eruptions of historical time, where expulsion of basalt, andesite, dacite and rhyolite magmas have produced effusive eruptions of Hawaiian and flood lava magnitudes, mixed eruptions of Strombolian to Plinian intensities, and explosive phreatomagmatic and magmatic eruptions spanning almost the entire intensity scale; from Surtseyan to Phreatoplinian in case of "wet" eruptions and Strombolian to Plinian in terms of "dry" eruptions.

\subsubsection{Effusive eruptions}

Effusive volcanism in Iceland features monogenetic central vent and fissure type volcanoes as well as central volcanoes where such eruptions often occur on short ring fracture segments or radial fissures. These eruptions produce basalt as well as dacite-rhyolite magmas, but effusion of andesite magma without conjunction of an explosive phase has yet to be recorded.

Effusive dacite to rhyolite eruptions are significant but relatively rare occurrence and generally have produced small volume $\left(<0.2 \mathrm{~km}^{3}\right)$ subaerial block lavas, coulees and domes as well as steep-sided subglacial domes and table mountains ranging in volume from $<0.1$ to $\sim 5 \mathrm{~km}^{3}$ (Sæmundsson, 1972; Blake, 1984; Macdonald et al., 1990; McGarvie et al., 1990; Tuffen et al., 2001, 2002). The aspect ratio of block lavas and coulees in Iceland is typically 0.02-0.05, which is very low compared to the typical aspect ratio of $\sim 0.1$ for the same flow types in other volcanic regions (Walker, 1973a). The low aspect ratio of the Icelandic block lavas and coulees is though to reflect relatively high $\left(\sim 1000^{\circ} \mathrm{C}\right)$ eruption temperature and fluidity (viscosity, $\sim 10^{5}$ to $10^{6} \mathrm{~Pa}$ ) of the dacite and rhyolite magmas.

It is useful, for purpose of description, to consider basaltic effusive eruptions in Iceland in terms of size (volume). Here they are grouped into small to medium $\left(<1 \mathrm{~km}^{3}\right)$ and large $\left(>1 \mathrm{~km}^{3}\right)$ volume events, where the latter group is distinguished as flood lava eruptions. Both groups can be further divided into eruptions of low and high magma discharge, although as such this subdivision reflects more end-member types in a continuous spectrum.

The small to medium volume group includes low-discharge events $\left(\leq 100 \mathrm{~m}^{3} / \mathrm{s}\right)$ that are typified by Hawaiian activity, forming tube-fed pahoehoe flows in subaerial and pillow lavas in subaqueous settings. These lava flows are characterized by thermally insulated transport and flow inflation, which can reach flow lengths of 20-30 km when the topography is favourable. The high-discharge end-member $\left(500-1000 \mathrm{~m}^{3} / \mathrm{s}\right)$ is characterized by Strombolian vent activity and formation of relatively short channel-fed a' a flows that advance relatively short distances $(\leq 10 \mathrm{~km})$ because of the inefficient thermal insulation of the transport system. Eruptions characterized by intermittent Hawaiian to Strombolian activity and highly pulsating discharge produce slabby to rubbly pahoehoe flows and the latter also happens to be the most common basalt flow type in Iceland (e.g. Keszthelyi et al., 2000, 2004; Guilbaud et al., 2005).

Lava shields are the principal representatives of low-discharge $\left(\leq 300 \mathrm{~m}^{3} / \mathrm{s}\right)$ flood lava eruptions. These eruptions produce vast pahoehoe flow fields (up to $20 \mathrm{~km}^{3}$ ) that are fed by a lava lake residing in the summit crater. The lava cone of each shield is essentially constructed by fountain-fed flows and overspills from the lake, whereas the surrounding lava apron is produced by tube-fed pahoehoe where insulated transport and flow inflation enables great flow length (up to $70 \mathrm{~km}$; e.g. Rossi, 1996; Thordarson, 2000). The high-discharge ( $\left.>1000 \mathrm{~m}^{3} / \mathrm{s}\right)$ flood lava events, such as the 1783-1784A.D. Laki and 934-938A.D. Eldgjá fissure eruptions, represent some of the greatest spectacles of Icelandic volcanism. Intensive research over the last two decades has significantly improved our knowledge of the progress and 


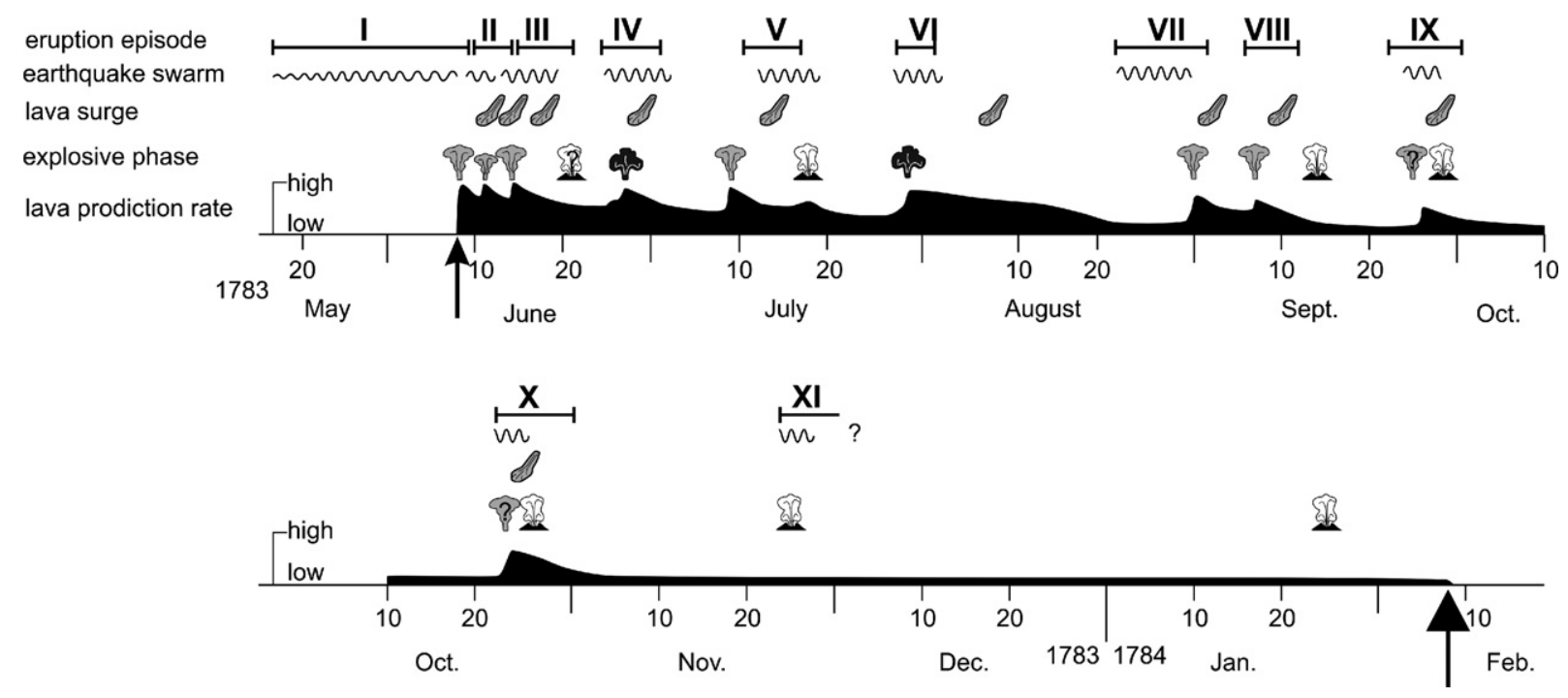

Fig. 9. Schematic illustration of sequence of events during the Laki-Grímsvötn eruptions. Extent of earthquake swarms is indicated by wiggly lines; fluctuations in lava discharge shown by shaded area (not to scale); eruption clouds denote explosive activity at Laki fissures; eruption clouds with a cone at the base denote explosive activity at Grímsvötn volcano; arrows indicate onset and termination of Laki eruption. The solid bars show the extent of each eruption episode, labelled I, II, III, etc. Modified from Thordarson and Self (1993).

mechanism of these eruptions, which in turn has enhanced our understanding of larger-scale flood basalt eruptions on Earth and Mars (e.g. Larsen, 1979, 2000; Thordarson and Self, 1993, 1996, 1998; Self et al., 1996, 1997; Thordarson et al., 1996, 1998, 2003a; Keszthelyi et al., 2000, 2004; Guilbaud et al., 2005). It has also demonstrated that over the last 1130 years, these events are the most significant of Icelandic eruptions in terms of environmental and climatic effects because of the huge amount of sulphur $\left(100-250 \mathrm{Mt}\right.$ of $\left.\mathrm{SO}_{2}\right)$ they release into the atmosphere (Thorarinsson, 1979; Metrich et al., 1991; Stothers, 1996, 1998; Thordarson et al., 1996, 2001, 2003b; Thordarson and Self, 2003; Oman et al., 2006) The high-discharge flood lava events are prolonged fissure eruptions that last for months to years and feature numerous eruption episodes (Fig. 9). Each episode appears to represent a rifting event (i.e. formation of a new fissure) and begins with a short-lived explosive phase followed by a longer phase of lava emissions. The initial explosive phase of each episode has duration of hours to days. It is typified by subplinian activity, or more rarely phreatomagmatic activity, which coincide with times of peak magma discharge (up to $7000 \mathrm{~m}^{3} / \mathrm{s}$ ). The subsequent effusive phase features relatively quiet effusion of lava at more moderate (1000-3000 $\left.\mathrm{m}^{3} / \mathrm{s}\right)$ and steadily declining discharge (Fig. 9). These eruptions have produced widespread tephra layers of substantial volumes $\left(0.4-1.2 \mathrm{~km}^{3} \mathrm{DRE}\right)$ as well as pahoehoe and rubbly pahoehoe lava flow fields that are some of the largest on Earth in post-glacial time.

\subsubsection{Explosive eruptions}

Explosive eruptions feature strongly in Icelandic volcanism and fall under the umbrella of three elementary styles; Surtseyan, Phreatoplinian and Plinian eruptions, thus representing the two basic classes of explosive eruptions-magmatic (dry) and phreatomagmatic (wet) explosions.

Over 50 explosive silicic (dacite and rhyolite) eruption are known to have occurred within 7 central volcanoes during the Holocene. At least 25 of these eruptions came from ice-capped or ice-covered central volcanoes (Larsen, 2002; Larsen et al., 2001) and were either phreatomagmatic or Phreatoplinian. Several of the remaining eruptions had a Phreatoplinian opening phase, including the 1875 Askja eruption (phase C; Self and Sparks, 1978). Existing data also indicates that the eruption frequency of explosive silicic eruptions in Iceland is high or one eruption every 200-300 years. Eruptions that emit $1-10 \mathrm{~km}^{3}$ of tephra $\left(0.25-2.5 \mathrm{~km}^{3}\right.$ DRE) occur on the average once every 1000 years (Thorarinsson, 1958, 1967a, 1970a; Larsen and Thorarinsson, 1977; Larsen et al., 2001; Larsen, 2002). Larger events (>10 km $\mathrm{km}^{3}$ tephra) occur roughly once in 100,000 years (Lacasse et al., 1995; Lacasse and Garbe-Schönberg, 2001) - equivalent to the highly active silicic systems like the Taupo Volcanic Zone in New Zealand (Houghton et al., 1995; Wilson et al., 1995). 


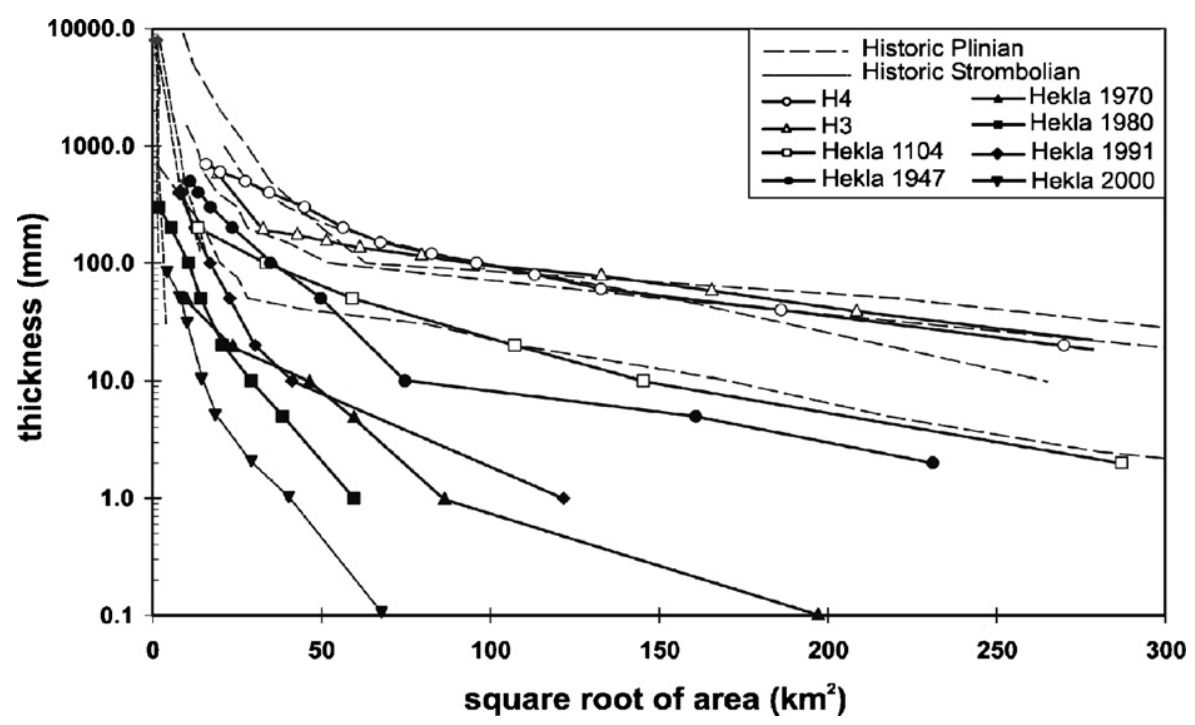

Fig. 10. Plot of thickness vs. square root of area for a selection of major Hekla eruptions. Icelandite-basalt icelandite eruptions are shown with solid symbols; rhyolite-icelandite with open symbols. For comparison we show data from four historical Plinian eruptions (St. Helens, 18 May 1980; Hudson, 1991; Quizapu, 1931; Novarupta, 1912) and four Strombolian eruptions (Kilauea Iki, 1959; Etna, 1971, Terceira B; Terceira E). Unpublished data, from B.F. Houghton and T. Thordarson (2006).

Plinian to subplinian rhyolite and dacite eruptions are confined to central volcanoes and are fairly typical in that they feature widespread tephra fall (Fig. 10) and more rarely pyroclastic density currents of significant volumes (e.g. Thorarinsson, 1958, 1967a, 1970b, 1979; Walker, 1962, 1966; Larsen and Thorarinsson, 1977; Larsen, 1984; Larsen et al., 1999, 2001; Sparks et al., 1981; Jorgensen, 1987; Lacasse et al., 1995; Lacasse, 2001; Róbertsdóttir et al., 2002). The post-glacial record incorporates several 1991-Pinatubo-size eruptions and includes three historical Plinian events (Hekla 1104, Öræfajökull 1362, 1875 Askja, phase D).

Phreatoplinian volcanism is the most diverse group of explosive eruptions in Iceland as it includes dacite to rhyolite eruptions from ice-free and ice-capped central volcanoes as well as large-volume basaltic fissure eruptions (Sparks et al., 1981; Larsen et al., 2001; Larsen, 1984, 2005). The unifying feature of phreatoplinian eruptions is that they all involve magma interacting with surface water, but yet exhibit enormous range of temporal and physical attributes. All have Walker $F$ indices of $\geq 80 \%$ and form thin blankets dispersed over areas of $10^{3}$ to $>10^{6} \mathrm{~km}^{2}$. In Iceland the volumes of phreatoplinian tephra vary by $>2$ orders of magnitude, from 0.01 to $5 \mathrm{~km}^{3}$. The Icelandic record includes the only verified historical example of silicic Phreatoplinian eruptions (1875 Askja C) on Earth and is one of the type-eruptions for this style of volcanism (Self and Sparks, 1978). We can now add the explosive fissure event of 870A.D. Vatnaöldur, which according to the properties and dispersal of the tephra represents a basaltic Phreatoplinian eruption (e.g. Larsen, 2005), producing a large and widespread tephra layer that covers more than half of the land surface in Iceland and has volume of $1-1.5 \mathrm{~km}^{3}$ (DRE).

Phreatomagmatic basaltic eruptions (i.e. Surtseyan; Walker, 1973b) are common in Iceland and include subglacial, subaerial and submarine eruptions from monogenetic central vent and fissure eruptions as well as eruptions from polygenetic central volcanoes. Due to recent activity at the ice-covered Grímsvötn volcano (i.e. eruptions in 1996, 1998 and 2004; Gudmundsson, 2003; Gudmundsson et al., 1997; Sigmundsson and Gudmundsson, 2004) as well as the recent and well-publicised eruption at Surtsey in 1963-1967 (e.g. Thorarinsson, 1967b, 1967c), it is fair to say that emergent subglacial and submarine phreatomagmatic eruptions have become new trademark events for Iceland volcanism.

About 70 eruptions have occurred on the Grímsvötn system in historical time, most of them presumably within the central volcano (Thorarinsson, 1974; Larsen et al., 1998; G. Larsen and M.T. Gudmundsson, unpublished data). Tephra volumes are difficult to verify due to large fall area within the ice cap but an estimated range is 0.01 to $>0.5 \mathrm{~km}^{3}$. Depending on factors such as the ice thickness over the eruption site, only a fraction of the erupted material is dispersed subaerially in many of the eruptions. The best available volume estimates are from the 1996 Gjálp event, $0.45 \mathrm{~km}^{3}$ DRE, and obtained by using calorimetric estimates derived from the mass of ice melted by the erupted magma as well as mapping of the tephra deposit by radio-echo sounding and other geophysical methods (e.g. Gudmundsson 
Table 3

Historical eruptions on the Katla volcanic system

\begin{tabular}{|c|c|c|c|c|c|}
\hline Katla volcanic system & Eruption year & Date & Length days & Preceding interval & Volume of airborne tephra ${ }^{a}$ \\
\hline Katla & (1999) & 18 July & & (44) & \\
\hline Katla & (1955) & 25 June & & (37) & \\
\hline Katla & 1918 & 12 October & 24 & 58 & Large \\
\hline Katla & 1860 & 8 May & 20 & 37 & Small \\
\hline Katla & 1823 & 26 June & 28 & 68 & Small \\
\hline Katla & 1755 & 17 October & $\sim 120$ & 34 & Large \\
\hline Katla & 1721 & 11 May & $>100$ & 61 & Moderate \\
\hline Katla & 1660 & 3 November & $>60$ & 35 & Moderate \\
\hline Katla & 1625 & 2 September & 13 & 13 & Large \\
\hline Katla & 1612 & 12 October & & 32 & Small \\
\hline Katla & 1580 & 11 August & & $\sim 80$ & Small \\
\hline Katla & $\sim 1500$ & & & & Large \\
\hline Katla & $15 \mathrm{ca}$. & & & & Small \\
\hline Katla & $\sim 1440$ & & & $\sim 24$ & Small \\
\hline Katla & 1416 & & & $\sim 59$ & Moderate \\
\hline Katla & $\sim 1357$ & & & $\sim 95$ & Moderate \\
\hline Katla & 1262 & & & 17 & Large \\
\hline Katla & 1245 & & & $\sim 66$ & Small \\
\hline Katla & $\sim 1179$ & & & & Small \\
\hline Katla & $12 \mathrm{ca}$. & & & & Small \\
\hline Eldgjá & $934 / 938$ & & & $\sim 16$ & Large \\
\hline Katla & $\sim 920$ & & & & Moderate \\
\hline Katla & $9 \mathrm{ca}$. & & & & Small \\
\hline
\end{tabular}

Data from Larsen (2000) and Eiríksson et al. (2004).

${ }^{\text {a }}$ Uncompacted tephra volume: small $<0.1 \mathrm{~km}^{3}$; moderate $0.1-0.5 \mathrm{~km}^{3}$; large $>0.5 \mathrm{~km}^{3}$.

et al., 1997, 2002; Gudmundsson, 2005). Jökulhlaup from the subglacial lake in the Grímsvötn caldera, which reach peak discharge of $40,000 \mathrm{~m}^{3} / \mathrm{s}$, can be triggered by ice melting associated with eruptions on the Grímsvötn system, as occurred in 1996 when Gjálp erupted (e.g. Gudmundsson et al., 1997). Sometimes the reverse is true; jökulhlaup trigger eruptions within the Grímsvötn caldera as occurred in 2004 (Sigmundsson and Gudmundsson, 2004).

Twenty Katla eruptions took place on fissures within the ice-filled Katla summit caldera on the Mýrdalsjökull central volcano in historical time (Table 3). All are subglacial phreatomagmatic eruptions and only produced basaltic tephra layers with volumes ranging from $\sim 0.01$ to $\sim 1 \mathrm{~km}^{3}$ (Larsen, 2000). All recorded Katla eruptions have been accompanied by jökulhlaup, the largest of which have peak discharge of $\sim 300,000 \mathrm{~m}^{3} / \mathrm{s}$ and flood areas of up to $400 \mathrm{~km}^{2}$ (Tómasson, 1996). These jökulhlaup's carry with them a load of ice as well as great quantities of primary volcanic debris, which exceeds the volume of the airborne tephra in some eruptions.

\subsubsection{Mixed eruptions}

Mixed eruptions form a distinctive category as they feature both explosive and effusive activity and are almost exclusively produced by andesite volcanism, which in historical time has been largely confined to the Hekla central volcano, with one exception; the 1973A.D. Eldfell eruption at Heimaey (e.g. Thorarinsson, 1967a, 1970a; Thorarinsson et al., 1973; Blackburn et al., 1976). Hekla eruptions are therefore taken here to typify this group. They follow a consistent pattern of activity with three phases. Each eruption has built over a few minutes into a vigorous subplinian to Plinian event (phase 1) characterized by high magma discharge (Fig. 11a). Phase 1 is typically of $<1 \mathrm{~h}$ duration irrespective of the maximum intensity of the eruption (e.g. Thorarinsson, 1976; Thorarinsson and Sigvaldason, 1972a; Grönvold et al., 1983; Gudmundsson et al., 1992; Larsen et al., 1992). The initial phase is followed by a severalhour-long transitional phase (phase 2) with simultaneous sustained emission of moderately widespread tephra fall and fountain-fed lava (Fig. 11b). The intensity of the eruption decreases sharply during phase 2 (Fig. 11a) with a sharply increasing lava/tephra ratio. Phase 3 activity is characterized by discrete Strombolian explosions and very low magma discharge $\left(<20 \mathrm{~m}^{3} / \mathrm{s}\right.$; Einarsson, 1949; Thorarinsson, 1976; Thordarson, unpublished observations in January and February 1991). This type of explosive and fountaining activity characterizes all historical Hekla eruptions that have been described in historical accounts. 

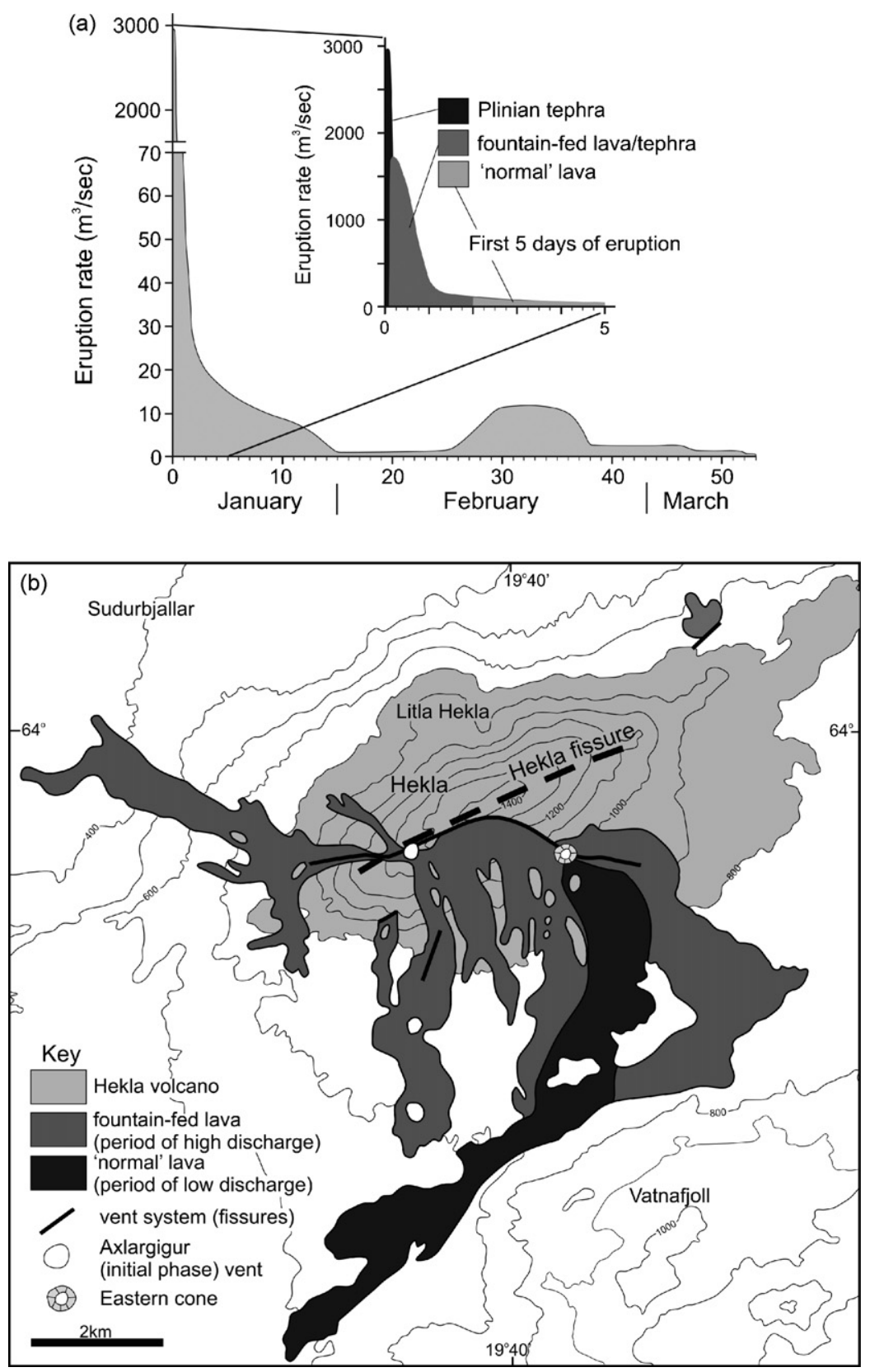

Fig. 11. (a) Diagram showing magma discharge vs. time during the 1991 Hekla eruption. Inset shows the magma discharge for phases 1-3 over the first 5 days of the eruption. Based Gudmundsson et al. (1992) and unpublished data by T. Thordarson (2006). (b) Map showing the 1991 Hekla vent system, main tephra fall sectors during phases 1 and 2 of the eruption as well as the distribution of phase 2 fountain-fed and phase 3 'normal' lava flows.

\section{Recent eruption history}

\subsection{Distribution and frequency of historical eruptions}

Volcanic activity in Iceland in historical time (i.e. over the last 1100 years) is a direct continuation of the prehistoric Holocene activity and generally confined to the same volcanic regions. A total of 16 volcanic systems have been 
volcanically active during this period. Of 9 volcanic systems on the RVZ-WVZ sector of the axial zone (Fig. 2), 4 have erupted in the last 1100 years. Those are the, Reykjanes-Svartsengi, Krýsuvík, Brennisteinsfjöll, and Langjökull systems on the WVZ-RVZ (Fig. 3; Jónsson, 1983; Jóhannesson, 1989; Jóhannesson and Einarsson, 1988a, 1988b; Einarsson and Jóhannesson, 1989; Sigurgeirsson, 1995). On the NVZ sector of the axial zone only three systems have produced eruptions in historical time, namely Theistareykir, Krafla and Askja (Fig. 3; Thorarinsson, 1963, 1965a; Björnsson et al., 1979; Björnsson, 1985; Larsen et al., 1979; Grönvold, 1984; Einarsson, 1991; Sæmundsson, 1991; Thorarinsson and Sigvaldason, 1962; Sigurdsson and Sparks, 1978; Sigvaldason, 1979, 1982; Sparks et al., 1981). In contrast, of the eight systems on the much younger EVZ, with the exception of Tindfjöll, have all recorded historical eruptions and four of these systems, Grímsvötn, Veidivötn, Hekla and Katla, have been profoundly active since the settlement of Iceland (e.g. Thorarinsson, 1967a, 1974, 1975; Jakobsson, 1979a; Larsen, 1984, 2000; Larsen et al., 1998; Björnsson and Einarsson, 1990; Gudmundsson et al., 1997; Thordarson et al., 2003a; Gudmundsson, 2005). On the intraplate volcanic belts, the Öræfajökull system on the ÖVB and Ljósufjöll on the SVB are the only two systems that have been active in historical time (e.g. Thorarinsson, 1958; Jóhannesson, 1977).

The eruption history in Iceland over the past 11 centuries is well documented and fairly robust. A detailed volcanological record, in form of vent structures, lava flows as well as tephra layers preserved in soils and glacial ice, is complemented by written accounts of volcanic eruptions that date back to the 12th and 13th century, which include references to eruptions extending back to the time of settlement (i.e. early 10th century). Comprehensive analysis of reliable written records in junction with systematic chronostratigraphic field studies has enabled an exceptionally accurate reconstruction of the historical eruptions (see references cited in caption to Fig. 12). Careful evaluation of the results from these studies reveals the occurrence of 205 historical events and of those; the products of 172 have been verified by identification of their deposits in the field (Fig. 12).

Of the 205 recorded events, $192(\sim 94 \%)$ represent single eruptions. Excluding the reported events because their characteristic eruption style has not been verified, bulk of the remaining 159 events are categorized as explosive eruptions or $124(78 \%)$ in total. The tally of mixed eruptions is $21(\sim 13 \%)$, whereas only $14(\sim 9 \%)$ count as effusive events. Thirteen $(\sim 6 \%)$ of the 205 events represent "Fires" (Table 4; Fig. 12). Although these "Fires" typically include two or more (up to 11) discrete eruptions, they are grouped here as individual events because the activity is characterized by styles ranging from effusive, mixed to explosive (Sigurdsson and Sparks, 1978; Einarsson and Jóhannesson, 1989; Grönvold, 1984; Einarsson, 1991; Thordarson and Self, 1993; Larsen, 2000; Thordarson et al., 2001, 2003a). Consequently, it is not always obvious what should be taken as one eruption. Out of the 13 recorded "Fires", $8(\sim 60 \%)$ featured mainly effusive activity, whereas the $5(\sim 40 \%)$ included explosive activity that produced substantial amount of tephra and in three of those "Fires" the volume of tephra exceeded $1 \mathrm{~km}^{3}$ (DRE).

Table 4

Historical events recorded as "Fires"

\begin{tabular}{|c|c|c|}
\hline Fires & No. of eruptions ${ }^{\mathrm{a}}$ & Sources \\
\hline Krafla 1975-1984 & 9 & Einarsson (1991), Sæmundsson (1991) \\
\hline Surtsey $1963-1967^{b}$ & $6-7$ & $\begin{array}{l}\text { Thorarinsson }(1964,1965 b, 1966,1968), \text { Jakobsson and Moore } \\
\text { (1982), Thordarson }(2000)\end{array}$ \\
\hline Askja 1921-1929 & $5-6$ & Thorarinsson (1963) \\
\hline Tröllahraun 1862-1864 & $2-3$ & Thorarinsson and Sigvaldason (1972b), Jónsson (1945) \\
\hline Skaftáreldar $1783-1785^{\mathrm{b}}$ & $10-11$ & Thordarson and Self (1993), Thordarson et al. (2003a, 2003b) \\
\hline Mývatnseldar 1724-1729 & $6-7$ & Thoroddsen (1907), Grönvold (1984), Sæmundsson (1991) \\
\hline Veidivötn 1477-b & $?$ & Larsen $(1984,2005)$ \\
\hline Illahraun 1227- & $?$ & $\begin{array}{l}\text { Jóhannesson and Einarsson (1988a), Einarsson and } \\
\text { Jóhannesson (1989) }\end{array}$ \\
\hline Krísuvíkureldar 1151- & $?$ & Jóhannesson and Einarsson (1988b) \\
\hline Y-Hellnahraun 10th century & $?$ & Einarsson et al. (1991), Jónsson (1983) \\
\hline Húsfellsbruni ca. 950 & $?$ & Kaldal et al. (1996), Jónsson (1983) \\
\hline Eldgjá ca. $934^{\text {b }}$ & $?$ & Larsen $(2000,2005)$, Thordarson et al. (2001) \\
\hline Vatnaöldur ca. $870^{\mathrm{b}}$ & $?$ & Larsen $(1984,2005)$, Kaldal (1985) \\
\hline
\end{tabular}

?: exact number of eruption is not known.

a All "Fires" include two or more eruptions, but number of eruptions is only given where the total is known with certainty.

b Fires that featured explosive activity producing significant amounts of tephra. 
(a)

Historical eruptions $870-2005$ AD

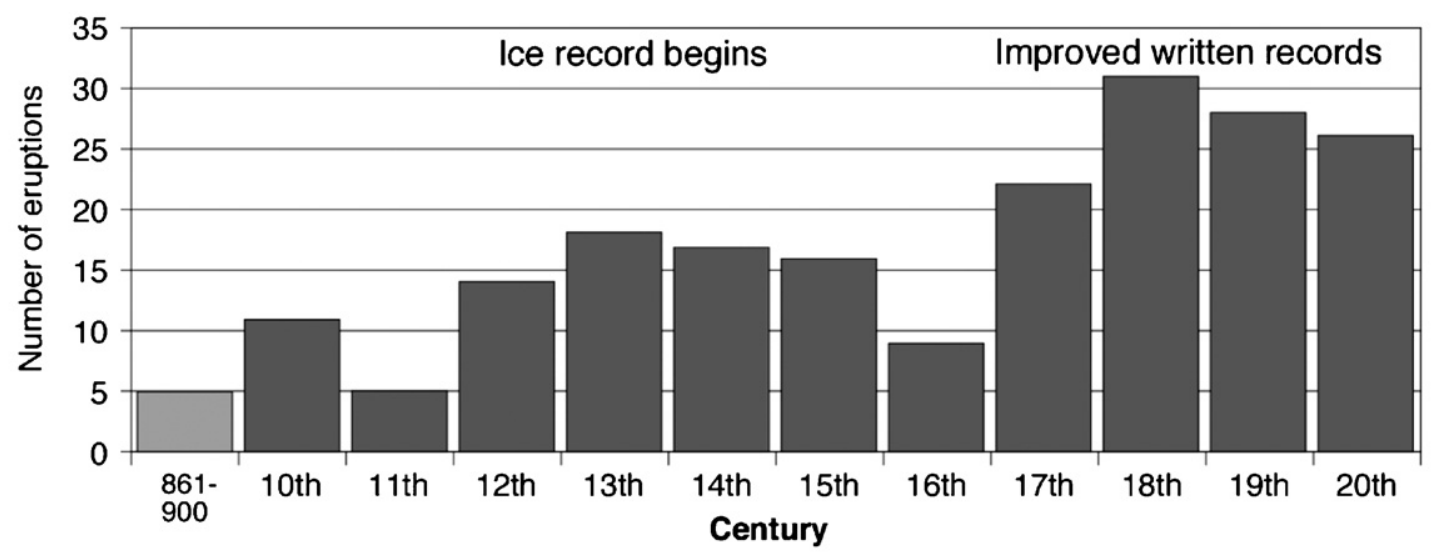

(b) Historical eruptions $870-2005$ AD

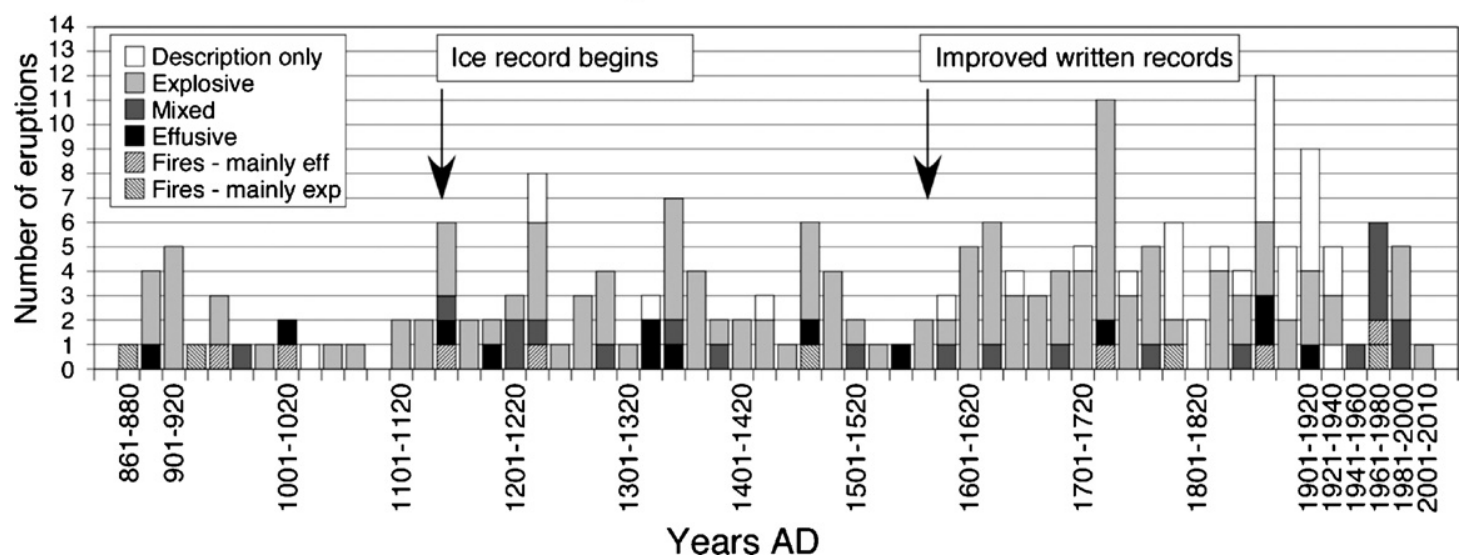

Fig. 12. Frequency of known volcanic events in Iceland since the Norse settlement around 870 , where the data is binned (a) per 100 years and (b) per 20 years. As the century of the pre-13th century Frambruni eruption is not known with certainty the total number of events used in the plot are 204, where 191 are counted individual eruptions and 13 as "Fires", which designates year to decade long volcanotectonic episodes with 2-11 eruptions. Number of eruptions in "Fires" pre-dating 1700A.D. is generally not known. The category "Reported" are volcanic events described in historical accounts but have not been verified by identification of their volcanic products. Based on data from Jónsson (1945), Thorarinsson (1950, 1958, 1963, 1965a, 1967a, 1970a, 1974, 1975), Thorarinsson and Sæmundsson (1979), Jakobsson (1979a), Jóhannesson (1977, 1983, 1984, 1987, 1989), Jóhannesson and Einarsson (1988a, 1988b), Jónsson (1978, 1983), Sæmundsson and Einarsson (1980), Sæmundsson (1991), Steinthórsson (1978), Larsen (1982, 1984, 2000), Larsen et al. (1992, 1998), Einarsson and Jóhannesson (1989), Grönvold et al. (1983, 1995), Sigurgeirsson (1992, 1995), Thordarson and Self (1993), Thordarson et al. (2003a, 2003b), Gudmundsson (2005), Eiríksson et al. (2004), Lacasse et al. (2004), Sigmundsson and Gudmundsson (2004) and G. Larsen and M.T. Gudmundsson (unpublished data, 2006).

The volcanic systems of the EVZ produced about $80 \%$ (137) of the 172 verified events. Bulk, or 132 events $(\sim 77 \%)$, were produced by the four most active volcanic systems on the EVZ, namely Grímsvötn, Hekla, Katla and Bárdarbunga-Veidivötn (Fig. 3a). The Grímsvötn system alone accounts for about 38\% of the verified historical eruptions and collectively the Bárdarbunga-Veidivötn $(\sim 14 \%)$, Hekla $(\sim 13 \%)$ and Katla $(\sim 12 \%)$ systems are responsible for another $\sim 39 \%$ of the number of events. The other three systems on the EVZ that have been active in historical time, Vestmannaeyjar, Eyjafjöll and Torfajökull account for 3\% of the events (Larsen et al., 1998; Larsen, 2002). The remainder is divided on other volcanic zones as follows: RVZ-WVZ, 9\%, NVZ, 5\%, ÖVB, $1 \%$ and SVB, $0.5 \%$. The origin of some tephra layers is still uncertain, which accounts for the remaining $4.5 \%$. If we consider the event frequency on the basis of the spatial distribution within the volcanic systems, then vast majority $(\sim 90 \%)$ involves activity at the central volcanoes or their corresponding domains and of those $\sim 70 \%$ are small basaltic eruptions. The remaining events represent eruptions that were confined to the fissure swarms and are always of basaltic composition. 
The number of known events since $\sim 870$ A.D. is plotted against time in 100 year bins and 20 year bins in Fig. 12a and b. On the latter graph the frequency of effusive, mixed and explosive events as well as "Fires" is also shown. Note that reported events are included here, even though they are not verified and a few that are doubtful. These plots clearly give the impression of a stepwise increase in eruption frequency from the settlement time to present. When binned according to centuries (Fig. 12a), the data indicates a mean eruption frequency of $\sim 10$ eruptions per century in the period 870-1200A.D., which increases to 15 eruptions per century during the Middle Ages (i.e. 1201-1600A.D.), and to 27 eruptions per century in the last 400 years. It is possible that this data reflects a real change in the eruption frequency, but there is no doubt that it is strongly amplified by the incompleteness of the eruption record in the earlier part of the period considered here. This perception is supported by the following knowledge:

(a) the earlier jump in eruption frequency around 1200A.D. coincides with the inception of tephra layers preserved in the glacier ice of Vatnajökull as documented in recent studies (e.g. Larsen et al., 1998; Larsen, 2002). These studies have substantially improved the post-1200A.D. record of small phreatomagmatic subglacial eruptions, in particular from the subglacial Grímsvötn and Bárdarbunga central volcanoes, and

(b) the apparent increase around 1600A.D. corresponds to the time of vast improvement in the quality and totality of written accounts on volcanic eruptions as is clearly revealed by the increase in number of eruptions categorized as "reported". It jumps from 6 in the pre-1600 record to 27 in the post-1600 record (Fig. 12b).

This record also shows that the repose intervals between eruptions vary from $<1$ year to $>20$ years and the longest periods of low activity are in the 11th and 16th centuries (Fig. 12b). These two excursions are not caused by documentation and represent real dips in the eruption frequency. The cause for these dips is unknown but in terms of timing they do not correspond to major climate cooling events reflected by increase in the volume of the ice caps and expansion of outlet glaciers.

The decadal binning of events is shown in Fig. 12b. In general it shows the same long-term trend, but here distinct peaks are seen to alternate with lows in the activity on decadal scale. This is most obvious for volcanoes below Vatnajökull ice cap, which reveal a second order trend with periodicity of $\sim 140$ year. This periodicity appears to reflect real changes in eruption frequency, where 40-80-year long intervals of high frequency alternate with equally long intervals of low eruption frequency (Larsen et al., 1998; Larsen, 2002). This periodicity mirrors the eruption frequency at the most active volcanic systems, in particular those of Grímsvötn and Bárdarbunga-Veidivötn, which are situated directly above the centre of the Iceland mantle plume/anomaly. Furthermore, major rifting episodes occurred on Grímsvötn system in 1783-1785A.D. and Bárdarbunga-Veidivötn system in 1477A.D.; in both cases during intervals of high activity. Peak strain release periods on the South Iceland Seismic Zone occur at intervals of about 140 years (Stefánsson and Halldórsson, 1988). These periods last for years to decades and feature earthquakes of magnitude 6-7 that release strain built up over long time. These peak periods of strain release have coincided with the observed high frequency eruption periods as far back as written record extend (i.e. 14th century).

It is also interesting to examine the frequency distribution of historical basaltic eruptions in relation to their size and geographical position within a particular volcanic system. Small $\left(<0.1 \mathrm{~km}^{3}\right)$ basaltic eruption at central volcanoes are the most frequent volcanic events $(\sim 70 \%)$ in the record reflecting the ease by which the shallow magma chambers erupt due to their small size and high recharge rates (i.e. overfilling). Although the recurrence period at most central volcanoes is on the order of several centuries, the eruption periodicity at the four most active central volcanoes in the EVZ is years to decades. On the other hand, the larger volume flood lava eruptions or their equivalent out on the fissure swarms represent only $10 \%$ of the documented events, which is consistent with the predicted eruption frequency for events fed directly from the larger and deeper reservoirs (Gudmundsson, 1986, 1987a, 1987b, 1988, 1995b, 2000). None of the system has more than two flood lava eruption in historical time, suggesting that their recurrence period within individual systems is on the time scale of hundreds to thousands of years.

The record of 205 events underscores the notion put forward by Thorarinsson and Sæmundsson (1979) that on average there are about 20 eruptions per century in Iceland. If we only consider the number of verified events (172) the average eruption frequency is 15 eruptions every 100 years. However, the data shown in Fig. 12 does not include all historical eruptions, because it underestimates the number of eruptions in the pre-1600s period when documentation of events is incomplete both in the written and geological records. Also, the recurring eruptions within the 13 fires are not counted here as individual events. With this in mind a more realistic average event frequency is that of the post-1600s 
record, or $\sim 25$ events per century (Fig. 12a) and consequently the eruption frequency rises to about 30 eruptions per century if the recurring eruptions of the Fires are counted individually.

\subsection{Magma output: volume of erupted magma}

Enhanced record on the number of historical eruptions and volume of their products allows for improved assessment on the total amount of magma erupted as lava and tephra over the last 1130 years. Although this record only takes into account the amount of erupted magma it provides new insights into the magma productivity in Iceland during historical time. It is important to keep in mind that these are estimates that are based on an improved, but not a fully complete, volume record. The volume of magma erupted as lava is better constrained than that of tephra, because overall the information on the aerial distribution and thicknesses of lava flows is more complete. In addition, the sizes of the largest historical lava flows, which are the most significant contributors to the volume of erupted magma (see below), are now known more accurately than before, as the estimated error on the volume calculations is less than $\pm 15 \%$. The constraints on the tephra volumes are poorer, mainly because the distribution of many small volume tephra layers, especially those produced by the $\sim 85$ subglacial eruptions from the Grímsvötn and Bárdarbunga central volcanoes, cannot be mapped in sufficient detail to allow robust volume calculations. However, the DRE volumes of subglacial eruptions on Grímvötn system in the 20th century have recently been estimated, giving an average volume of $\sim 0.04$ and $\sim 0.3 \mathrm{~km}^{3}$ for eruptions inside and outside the caldera, respectively (Gudmundsson, 2005). The tephra volume produced by the Grímsvötn central volcano in historical time is estimated by assuming that the average DRE volumes of subglacial eruptions within and outside the Grímsvötn caldera during the 20th century is representative for all historical eruptions. Consequently, the inferred uncertainties on the volume figures presented here are estimated at $\pm 25 \%$.

The total amount of lava and tephra produced over the last 1100 years is estimated at $\sim 122 \mathrm{~km}^{3}$, which is equivalent to $87 \mathrm{~km}^{3}$ of magma when dense rock equivalent (DRE) volume is used for the tephra (Table 5). Note that here DRE is taken to be equal to solidified lava. Basaltic eruptions are the greatest contributors as mafic magmas account for $\sim 79 \%$ of the total volume of erupted magma. About $16 \%$ is intermediate and $\sim 5 \%$ is silicic magmas (Table 5). However, it

Table 5

Volume of erupted magma according to rock type and volcanic regions

\begin{tabular}{|c|c|c|c|c|c|c|}
\hline Rock type & Lava & Tephra & Tephra (DRE) & Total & Total (DRE) & $\%$ DRE \\
\hline Basalt & 50 & 44 & 19 & 94 & 69 & 79 \\
\hline Andesite & 11.5 & 4.5 & 2 & 16 & 13.5 & 16 \\
\hline Rhyolite and dacite & 0.5 & 11 & 3.5 & 11.5 & 4 & 5 \\
\hline Sum & $\sim 62$ & $\sim 60$ & $\sim 25$ & $\sim 122$ & $\sim 87$ & \\
\hline \multicolumn{7}{|l|}{ Volcanic zones } \\
\hline Reykjanes Volcanic Zone and West Volcanic Zone & 11 & 1 & 0.5 & 11.5 & 11.5 & 13 \\
\hline North Volcanic Zone & 1 & 3 & 1 & 4 & 2 & 2.5 \\
\hline East Volcanic Zone & 50 & 49 & 21 & 99 & 71 & 82 \\
\hline Öræfajökull and Snæfellsnes Volcanic Belts & 0.2 & 6.5 & 2 & 6.7 & 2.2 & 2.5 \\
\hline Sum & $\sim 62$ & $\sim 60$ & $\sim 25$ & $\sim 122$ & $\sim 87$ & \\
\hline \multicolumn{7}{|l|}{ Four most productive volcanic systems } \\
\hline Katla & 18 & $15^{\mathrm{a}}$ & $6-7^{\mathrm{a}}$ & 33 & 25 & 36 \\
\hline Grímsvötn & 15 & $14^{\mathrm{b}}$ & $6^{\mathrm{b}}$ & 29 & 21 & 30 \\
\hline Hekla & 11 & 6 & 2 & 17 & 13 & 19 \\
\hline Bárdarbunga-Veidivötn & 5 & 13 & 5 & 18 & 10 & 15 \\
\hline Sum & 49 & 48 & 19-20 & 97 & 69 & \\
\hline
\end{tabular}

Note: volume estimates for the Grímsvötn Volcanic System are based on the assumption that average DRE volume of 20th century eruptions within and outside the Grímsvötn caldera (=0.04 and $0.3 \mathrm{~km}^{3}$, respectively; Gudmundsson (2005) is representative for the activity in historical time (see text for further details).

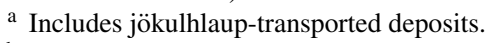

b Includes subglacial deposits. 
should be noted that the four event, the 934-938A.D. Eldgja $\left(\sim 20 \mathrm{~km}^{3}\right), \sim 950$ A.D. Hallmundarhraun $\left(\sim 8 \mathrm{~km}^{3}\right)$, pre13th century Frambruni $\left(\sim 4 \mathrm{~km}^{3}\right)$ and 1783-1784A.D. Laki $\left(\sim 15 \mathrm{~km}^{3}\right)$ flood lava eruptions (Larsen, 2000; Thordarson et al., 2001; Sinton et al., 2005; Haukur Jóhannesson, person. commun.; Thordarson and Self, 1993), account for more than one half $(54 \%)$ of the total erupted volume and $\sim 68 \%$ of the mafic magma component. Furthermore, $\sim 95 \%$ of the intermediate magma is produced by one volcano, namely Hekla. The 1362A.D. Öræfajökull eruption is the main contributor to the silicic magma budget, accounting for $\sim 50 \%$, whereas bulk of the rest split about evenly between two other central volcanoes (i.e. Hekla and Askja).

The volume of erupted magma in historical time is not evenly distributed among the active volcanic zones and belts. The output is dominated by the EVZ, which accounts for $\sim 82 \%\left(\sim 71 \mathrm{~km}^{3}\right)$ of the total volume, followed by the RVZ-WVZ producing $\sim 13 \%$, whereas the NVZ and the intraplate volcanic belts only account for $\sim 2.5 \%$ each (Table 5). It is noteworthy that events within the axial zone (i.e. RVZ-WVZ and NVZ) have collectively produced $\sim 13.5 \mathrm{~km}^{3}$ of the magma in historical times, which is just under $20 \%$ of the output on the EVZ. The volume of erupted magma is neither evenly distributed among the volcanic systems. This is nowhere more ubiquitous than in the EVZ where four volcanic systems, i.e. Katla $\left(\sim 25 \mathrm{~km}^{3}\right)$, Grímsvötn $\left(\sim 21 \mathrm{~km}^{3}\right)$, Hekla $\left(\sim 13 \mathrm{~km}^{3}\right)$ and Veidivötn $\left(\sim 10 \mathrm{~km}^{3}\right)$, have collective magma outputs of about $69 \mathrm{~km}^{3}$, corresponding to $\sim 97 \%$ of the output by EVZ and $\sim 79 \%$ of the total erupted magma volume (Table 5). Furthermore, three flood lava events (i.e. Eldgjá, Frambruni and Laki) account for more than one half $(\sim 55 \%)$ of the EVZ output and alone the Hallmundarhraun flood lava eruption represents $\sim 70 \%$ of the RVZ-WVZ output over the last 1130 years.

Although volume estimates are not as robust as is desirable and have fairly large uncertainties $( \pm 25 \%)$, they are of the correct magnitude and as such provide a basis for some general conclusions concerning magma output in Iceland over the last 1130 years.

First, our value, $87 \mathrm{~km}^{3}$, for total volume of erupted magma is about two times greater than the $42 \mathrm{~km}^{3}$ (DRE) reported previously by Thorarinsson and Sæmundsson (1979). However, the proportions of mafic (79\%), intermediate $(16 \%)$ and silicic (5\%) magmas are essentially unchanged (Table 5). This increases the output of erupted magma in Iceland to $\sim 8 \mathrm{~km}^{3}$ per century or more than double the output by currently active volcanoes in Hawaii, which is estimated at $\sim 3.6 \mathrm{~km}^{3}$ (range, $2.1-4.3 \mathrm{~km}^{3}$ ) per century (e.g. Swanson, 1972; Dvorak and Dzurisin, 1993). Furthermore, this output rate is about $52 \%$ of the inferred output rate of the Columbia River Basalt Group at time when activity was at its peak, but only $8 \%$ of the estimated peak output rate for the Deccan traps (Tolan et al., 1989; Self et al., 2006). The figures given here are minimum values for the magma productivity at all of the volcanic provinces considered, because they do not account for the volume of non-erupted magma stored in intrusions within the crust. These figures are likely to double or triple if intrusive volumes are included (i.e. Dvorak and Dzurisin, 1993).

Second, one inescapable, but important conclusion that can be extracted from this data is that the EVZ is the dominant contributor to the productivity in historical time, accounting for $\sim 79 \%\left(\sim 69 \mathrm{~km}^{3}\right)$ of the total volume of erupted magma, while the axial zone (i.e. RVZ-WVZ and NVZ) only accounts for 15-16\%. Moreover, bulk of the magma output in the EVZ (97\%) and in Iceland as a whole (77\%) is accommodated by the four volcanic systems of Katla, Grímsvötn, Hekla and Bárdarbunga-Veidivötn (Table 5). It is not intuitively obvious why these four systems are the most productive ones in Iceland. Although, two of the systems (i.e. Grímsvötn and Bárdarbunga-Veidivötn) are situated directly above the presumed centre of the Iceland mantle plume/anomaly and thus most magmatically active part of Iceland, the other two (i.e. Katla and Hekla) are situated considerable distance to the west (Fig. 3a). Furthermore, the Katla and Grímsvötn, which are by far the two most productive systems in historical time, feature well developed caldera-capped central volcanoes but poorly developed (embryonic) fissure swarms (Table 1). However, irrespective of the specific cause, it is clear that this part of the EVZ has been the main corridor for the magma to the surface in historical time.

Third, it is noteworthy that the four flood lava eruptions, 934-938A.D. Eldgjá, 950A.D. Hallmundarhraun, pre-13th century Frambruni and 1783-1784A.D. Laki events, account for $\sim 54 \%$ of the magma output over the last 1130 years. These events also produced the only lava flows that extend beyond the limits of the active volcanic zones. Therefore, in accordance to the Pálmason (1973) spreading model, they have the highest potential for preservation within the Icelandic stratigraphic succession of the modern volcanic products. As such, they may represent the rate by which lava is added to the plateau basalt pile of Iceland, but it is clear from the Tertiary succession, which for example includes numerous central volcanoes, that volcanic structures with distribution limited to the active volcanic zones are also incorporated into the long-term stratigraphic record (e.g. Jóhannesson and Sæmundsson, 1998). 
Table 6

Historical eruptions on the Hekla volcanic system

\begin{tabular}{|c|c|c|c|c|}
\hline Year of eruption (A.D.) & Tephra $\left(\mathrm{km}^{3}\right)$ & Tephra DRE $\left(\mathrm{km}^{3}\right)$ & Lava $\left(\mathrm{km}^{3}\right)$ & Preceding interval (years) \\
\hline \multicolumn{5}{|l|}{ Hekla central volcano } \\
\hline 2000 & 0.01 & 0.004 & 0.17 & 9 \\
\hline 1991 & 0.02 & 0.01 & 0.15 & 10 \\
\hline 1980-1981 & 0.06 & 0.026 & 0.12 & 10 \\
\hline 1970 & 0.07 & 0.03 & 0.2 & 22 \\
\hline $1947-1948$ & 0.18 & 0.08 & 0.8 & 101 \\
\hline 1845 & 0.23 & 0.1 & 0.63 & 77 \\
\hline $1766-1768$ & 0.4 & 0.18 & 1.3 & 73 \\
\hline 1693 & 0.3 & 0.13 & 0.9 & 56 \\
\hline 1636 & 0.18 & 0.08 & 0.5 & 39 \\
\hline 1597 & 0.29 & 0.13 & 0.9 & 86 \\
\hline 1510 & 0.32 & 0.14 & 1.0 & 120 \\
\hline 1389 & 0.15 & 0.07 & 0.5 & 47 \\
\hline 1341 & 0.18 & 0.08 & 0.5 & 40 \\
\hline 1300 & 0.5 & 0.22 & 1.5 & 78 \\
\hline 1222 & 0.04 & 0.02 & 0.1 & 15 \\
\hline 1206 & 0.4 & 0.18 & 1.2 & 46 \\
\hline 1158 & 0.33 & 0.1 & 0.1 & 53 \\
\hline 1104 & 2 & 0.61 & & $>230$ \\
\hline Total & 5.6 & 2.2 & 10.8 & \\
\hline \multicolumn{5}{|l|}{ Hekla fissure swarm } \\
\hline 1913 & & & & 35 \\
\hline 1878 & & & & 153 \\
\hline 1725 & & & & 171 \\
\hline 1554 & & & & 114 \\
\hline 1440 & & & & $?$ \\
\hline Total & & & (est. 0.6) & \\
\hline
\end{tabular}

Data from Thorarinsson (1967a, 1970a, 1970b), Jakobsson (1979a, 1979b); Larsen et al. (1999), Gudmundsson et al. (1992), Haraldsson et al. (2002), Ólafsdóttir et al. (2002). Italicised numbers in column 3 are anticipated lava flow volumes using the mean ratio of tephra and lava calculated from eruptions where both values are known.

\subsection{Eruption history of selected volcanic systems}

In order to provide a more detailed insight into volcanism in Iceland we present here a brief overview of the historical activity on selected volcanic systems. The selection includes the Hekla, Katla, Grímsvötn, and Bárdarbunga-Veidivötn on the EVZ, because they represent the four most active systems in the country. Also included is the Krafla volcanic system on the NVZ, because it has featured "Fires" that have provided critical insight into basaltic magmatism and precursors that precede eruptions on the axial zone.

\subsubsection{Hekla volcanic system}

Since the first historical eruption in 1104A.D., the Hekla volcanic system has registered 23 events, which make it the second most active system in Iceland (Table 6). Majority of these eruptions (18) are centred on the Hekla central volcano, occurring along the $5 \mathrm{~km}$-long, southwest-northeast trending summit fissure as well as on radial fissures on the flanks of the edifice (Thorarinsson, 1967a, 1970a; Thorarinsson and Sigvaldason, 1972a; Grönvold et al., 1983; Gudmundsson et al., 1992). The last eruption at Hekla proper was in February 2000 (Lacasse et al., 2004). The remaining five are basaltic fissure eruptions that took place on the fissure swarm outside the domain of the central volcano. The oldest is from around 1440A.D. whereas the youngest occurred in 1913A.D. (Bárdarson, 1930; Thorarinsson, 1967a, 1970a; Jakobsson, 1979a).

With the exception of the 1104A.D. rhyolite Plinian eruption, which was purely explosive, the remaining 17 eruptions from the Hekla central volcano are known or inferred to have been mixed eruptions producing significant amounts of both tephra and lava. The frequency of eruptions at Hekla volcano over the last 1100 years has been on the order of 
one to three eruptions per century. The exception is the last (i.e. 20th) century, when the volcano featured a tally of five eruptions, each being of less magnitude than the previous one. The composition of the erupted magma ranges from dacite to basaltic andesite. The mixed Hekla eruptions typically begin with a short-lived ( $0.5-2 \mathrm{~h}$ long) Plinian or subplinian phase that is immediately followed by a longer-lasting phase of lava fountaining and effusion (Figs. 10 and 11). The silica content of the first erupted magma in each eruption is determined by the preceding interval of quiescence and since 1389 the last magma to appear has silica content of $52-54 \%$.

The tephra fall deposit and its dispersal is known for all of the historical eruptions. The volume of tephra produced by individual historical eruptions ranges from 0.01 to $2 \mathrm{~km}^{3}\left(=0.004-0.6 \mathrm{~km}^{3}\right.$ DRE) and the cumulative volume is about $5.6 \mathrm{~km}^{3}$ or $\sim 2.2 \mathrm{~km}^{3}$ DRE. The extent and thickness of the last seven lava flows from Hekla (i.e. post-1700s) is well known and volumes of these lavas ranges from 0.1 to $1.5 \mathrm{~km}^{3}$ (Table 6). Most of the pre-1700s lavas are now completely buried by these younger flows and flows of seven eruptions (e.g. A.D. 1693, 1636, 1597, 1510, 1341, 1222 and 1206) are not exposed. However, the oldest identified flow is dacite lava from the eruption in 1158A.D. (Sigmarsson et al., 1992) and the first one mentioned in historical accounts is that of the eruption in 1389A.D. (Thorarinsson, 1967a, 1970a). Thus, we assume that all historical Hekla eruptions, except the one of 1104, formed lava flows and we have estimated their volume using the mean ratio of lava to tephra for the post-1700 eruptions. The volume of exposed and mapped lava flows is $\sim 4 \mathrm{~km}^{3}$ but the estimated historical lava volume is $\sim 11 \mathrm{~km}^{3}$ (Table 6). The five basaltic fissure eruptions have a collective lava volume of $\sim 0.6 \mathrm{~km}^{3}$ (Jakobsson, 1979a), making the total volume of erupted magma from Hekla in historical time is $\sim 13-14 \mathrm{~km}^{3}$.

\subsubsection{Katla volcanic system}

Katla is third most active system in historical time with at least 21 eruption since the late 9th century (Larsen, 2000), which all have produced evolved FeTi-basalt with rare phenocrysts of plagioclase, olivine and augite (e.g. Jakobsson, 1979a). With the exception of one, these eruptions took place on fissures within the ice-filled Katla summit caldera on the Mýrdalsjökull central volcano (Table 3). All are subglacial phreatomagmatic eruptions and only produced basaltic tephra layers with volumes ranging from $\sim 0.01$ to $>1 \mathrm{~km}^{3}$ (e.g. Thorarinsson, 1975). All recorded Katla eruptions have been accompanied by jökulhlaups, the largest of which have peak discharge of $\sim 300,000 \mathrm{~m}^{3} / \mathrm{s}$ and flood areas of up to $400 \mathrm{~km}^{2}$ (Tómasson, 1996). The jökulhlaup are loaded with glacier ice and carry forward large quantities of primary tephra, which in some eruptions exceeds the mass of the airborne tephra. By far the largest eruption on the Katla system, the 934-938A.D. Eldgjá flood lava eruption, took place on a $75 \mathrm{~km}$ long discontinuous volcanic fissure extending from the Katla caldera in the southwest to the tip of Vatnajökull in the northeast. The southwest $15 \mathrm{~km}$ opened up below the Mýrdalsjökull ice cap with phreatomagmatic activity that produced a minimum of $4 \mathrm{~km}^{3}\left(\sim 1.3 \mathrm{~km}^{3} \mathrm{DRE}\right)$ of basaltic tephra (Larsen, 2000). Effusive activity prevailed on the subaerial part of the fissure, producing about $0.5 \mathrm{~km}^{3}$ (DRE) of tephra and $18.6 \mathrm{~km}^{3}$ of lava covering an area of $\sim 780 \mathrm{~km}^{2}$. The total $\mathrm{SO}_{2}$ emissions from Eldgjá amount to $\sim 220 \mathrm{Mt}$, corresponding to $\sim 400 \mathrm{Mt}$ of sulphuric aerosols, making it the greatest volcanic pollution event from flood lava eruptions in historical times (Thordarson et al., 2001).

The volume of lava erupted in historical time is $\sim 18.6 \mathrm{~km}^{3}$ and that of airborne tephra and jökulhlaup-deposited volcanic debris is $\sim 15 \mathrm{~km}^{3}$ (=6-7 km $\mathrm{km}^{3} \mathrm{DRE}$ ). Thus, the total volume of erupted magma is about $25 \mathrm{~km}^{3}$, making the Katla volcanic system the most productive in historical time. The eruption frequency has been one to three eruptions per century except for the period of 11th and 12th century, when the system went through an $\sim 240$-year-long interval of quiescence in the wake of the Eldgjá eruption in the 930 s (Table 3). It is noteworthy that Katla eruptions have never started in the winter and the preferred month of eruption is October.

\subsubsection{Grímsvötn volcanic system}

About 70 eruptions are attributed to the Grímsvötn system (Fig. 13), making it the most active volcanic system in historical time in terms of eruption frequency (Larsen, 2002). The central volcano with the Grímsvötn caldera and about $60 \mathrm{~km}$ of the $90 \mathrm{~km}$ long SW-trending fissure swarm lie below the Vatnajökull ice cap (Sæmundsson, 1978). The Laki flood lava eruption in 1783-1784 took place on a $27 \mathrm{~km}$ long continuous volcanic fissure in the ice-free part of the Grímsvötn system and produced about $14.7 \mathrm{~km}^{3}$ of lava, covering an area of about $565 \mathrm{~km}^{2}$, and about $0.4 \mathrm{~km}^{3}$ (DRE) of tephra (Thordarson and Self, 1993). The Laki eruption released about $120 \mathrm{Mt}$ of $\mathrm{SO}_{2}$ into the atmosphere, producing an aerosol cloud that covered the top northern quarter of the globe and produced significant environmental and climatic effects (Thordarson et al., 1996; Thordarson and Self, 2003; Chenet et al., 2005; Oman et al., 2006). All other historical eruptions took place on the ice-covered part of the system. Most of the 64 verified eruptions are 
Grímsvötn volcanic system 1200-2005 - explosive and partly explosive basaltic eruptions

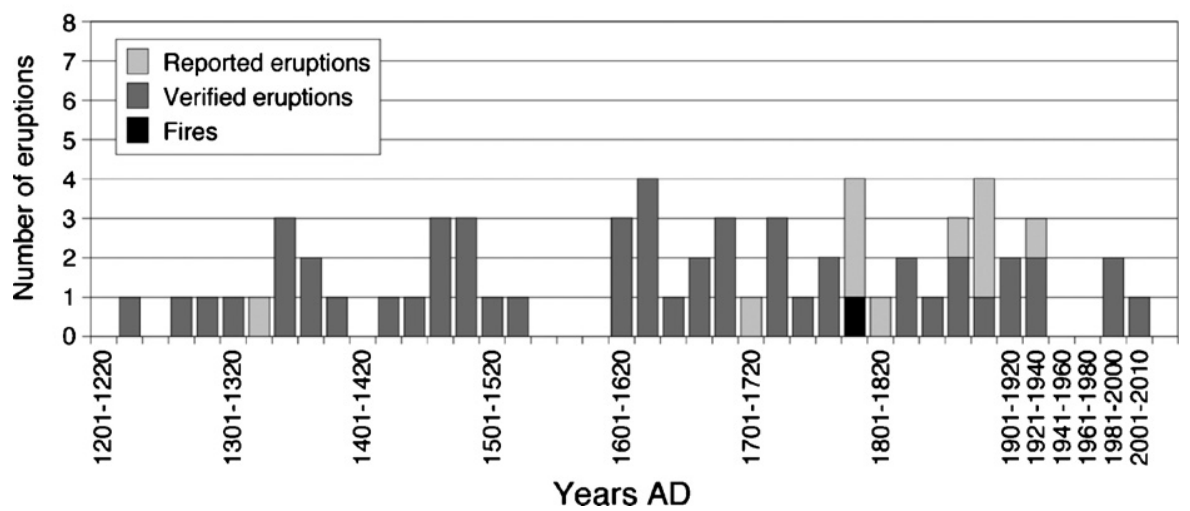

Fig. 13. Frequency of eruptions on the Grímsvötn volcanic system since 1200A.D. Two gaps in activity, 1540-1600A.D. and 1940-1980A.D. are evident from the data, as well as five frequency peaks that are spaced at intervals of 100-160 years. Pre-1300A.D. data is incomplete and therefore not included. Data from Thorarinsson (1974), Steinthórsson (1978) and Larsen et al. (1998) as well as unpublished data by G. Larsen and M.T. Gudmundsson (2006).

thought to have occurred within the Grímsvötn caldera whereas 10-11 eruptions may have occurred below thicker ice cover outside the caldera, as in the case of the 1996 Gjálp eruption (Thorarinsson, 1974; Gudmundsson and Bjornsson, 1991; Gudmundsson, 2005; G. Larsen and M.T. Gudmundsson unpublished data, 2006). Tephra volumes are difficult to verify due to large fall area within the ice cap but an estimated range is 0.01 to $>0.5 \mathrm{~km}^{3}$. Depending on factors such as the ice thickness over the eruption site, only a fraction of the erupted material is dispersed subaerially in many of the eruptions. The best available volume estimates have been obtained by using the mass of ice melted by the magma erupted in the 20th century events (Gudmundsson et al., 1997; Gudmundsson, 2003, 2005), indicating average volumes of $\sim 0.04 \mathrm{~km}^{3}$ within the Grímsvötn caldera and $\sim 0.3 \mathrm{~km}^{3}$ for eruptions outside of the caldera. Jökulhlaup from the subglacial lake in the Grímsvötn caldera, which reach peak discharge of $40,000 \mathrm{~m}^{3} / \mathrm{s}$, can be triggered by ice melting associated with eruptions on the Grímsvötn system, as occurred in 1996 when Gjálp erupted (e.g. Gudmundsson et al., 1997). Sometimes the reverse is true; jökulhlaup trigger eruptions within the Grímsvötn caldera as occurred in 2004 (Sigmundsson and Gudmundsson, 2004 and references therein). The eruption pattern of Grímsvötn is characterized by distinct 50-80-year-long periods of high eruption frequency alternating with equally long periods of low eruption frequency (Fig. 13; Larsen et al., 1998). The shortest and longest periods are 100 and 160 years and the average is $\sim 140$ years. This periodicity coincides with major strain release events on the South Iceland Seismic Zone and the prediction is that that the next 60 years will be an interval of high eruption frequency, peaking around 2030-2040A.D.

\subsubsection{Bárdarbunga-Veidivötn volcanic system}

At least 23 eruptions (verified) are attributed to the Bárdarbunga-Veidivötn system, which makes it the second most active in historical time (Larsen, 2002). The central volcano, Bárdarbunga, and nearly $60 \mathrm{~km}$ of the $190 \mathrm{~km}$ long fissure swarm lie below northwestern part of the Vatnajökull ice cap (Sæmundsson, 1978). Most of the historical eruptions have taken place on the ice-covered part of the volcanic system, emitting small to moderate volumes of basaltic tephra. Here it is assumed that the average magma volume in these eruptions is similar to that of the intra-caldera Grímsvötn eruptions or $0.04 \mathrm{~km}^{3}$ DRE. Several of the historical eruptions (i.e. A.D. 1684, 1716, 1717, and 1726) are known to have generated jökulhlaup that were discharged to the north through the channel system of Jökulsá á Fjöllum (Thorarinsson, 1950).

Three of the historical eruptions, that of 1862-1864A.D. Tröllagígar, 1477A.D. Veidivötn and 870A.D. Vatnaöldur, occurred on long fissures on the ice-free part of the system, although concurrent subglacial eruptions at Bárdarbunga are inferred from contemporary accounts and dispersal pattern of the corresponding tephra layers (Thorarinsson and Sigvaldason, 1972b; Larsen, 1984). The Vatnaöldur and Veidivötn eruptions emanated from $>60 \mathrm{~km}$ long discontinuous fissure vent systems that in parts cut through areas where the groundwater table was at or near the surface. Explosive activity dominated in the wet areas, producing $5-10 \mathrm{~km}^{3}$ of freshly fallen basaltic tephra; in dry areas small lavas were formed (Larsen, 1984, 2005). Transitory tephra dammed lakes were formed as a result of these eruptions. The $\sim 870$ and 

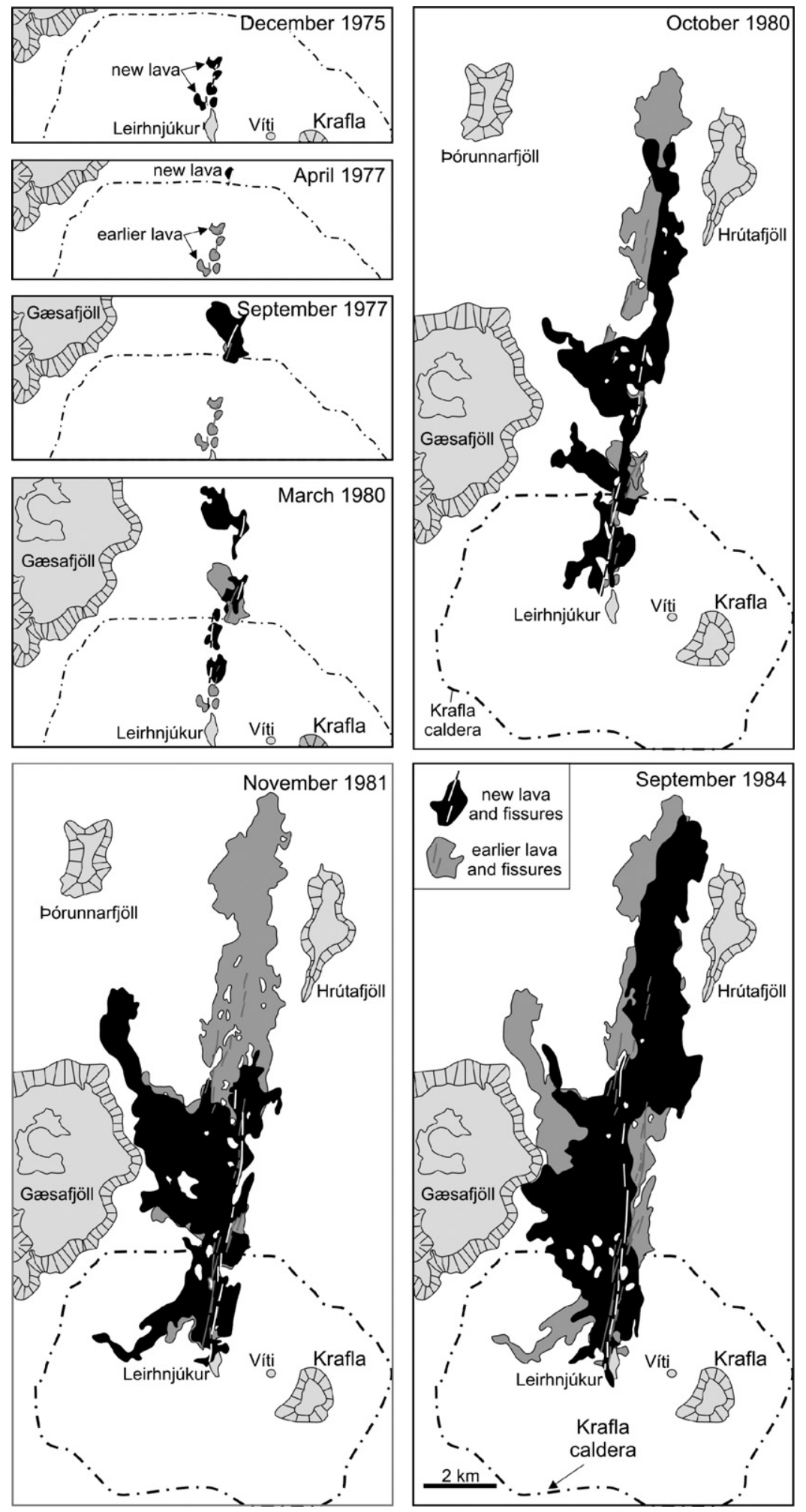

Fig. 14. Maps showing the time progression of vent and lava flows produced by the eruptions of the 1975-84 Krafla Fires. Modified from Sæmundsson (1991). 
1477 tephra fall, together with the basaltic Eldgjá and rhyolitic Öræfajökull tephra fall deposits constitute the largest tephra layers deposited in Iceland in historical time (Thorarinsson, 1958; Larsen, 1984, 2000, 2005). Rhyolitic, mixed and/or hybrid (rhyolite-basalt) tephra and lava was erupted on the southwest ends of the Vatnaöldur and Veidivötn fissures where the SW tip of the vent systems extended into the silicic Torfajökull central volcano (Mörk, 1984; McGarvie, 1984; McGarvie et al., 1990).

\subsubsection{Krafla}

Two major volcanotectonic episodes have occurred at the Krafla volcanic system in historical times, both within the last 250 years: the 1724-1729 Mývatn Fires and the 1975-1984 Krafla Fires, signifying periodic rifting and faulting along the plate boundary confined to a single system. Both rifting episodes included a series of four (Mývatn Fires) and nine (Krafla Fires) small $\left(<0.2 \mathrm{~km}^{3}\right)$ effusive eruptions that occurred on fissures within the Krafla caldera volcano as well as on the nearby sectors of the fissure swarms (e.g. Einarsson, 1991; Sæmundsson, 1991). The Mývatn Fires also featured one phreatic central vent eruption at the start of the rifting episode. Thus, the tally of historical eruptions within the Krafla system is 14 and volume of erupted magma is $\sim 0.5 \mathrm{~km}^{3}$. These rifting episodes have provided valuable insights into the mechanics of volcanic systems in Iceland, especially the Krafla Fires and therefore it is summarised here in some detail.

The volcanotectonic episode of the Krafla Fires began in December 1975 and lasted until September 1984 (Einarsson, 1991; Sæmundsson, 1991). Signs of renewed activity within the Krafla volcanic system was an increase in earthquake activity in June 1975. Initially the earthquake activity was confined to the region below the caldera, but quickly spread out along the fissure swarm to the north coast at Öxarfjörður and south towards Lake Mývatn (e.g. Björnsson et al., 1979; Brandsdóttir and Einarsson, 1979; Björnsson, 1985). This rifting was associated with a $1.5 \mathrm{~m}$ widening of the fissure swarm and a $2 \mathrm{~m}$ deep graben was formed along the central part of the fissure system. The first eruption broke out from a short fissure at Leirhnjúkur, producing a small lava flow and a few explosions (Fig. 14). It was followed by an immediate subsidence within the caldera floor and subsequent but gradual inflation of the caldera floor over the next few months. This pattern of gradual inflation and sudden deflation recurred several times during the episode. Each cycle began with inflation of the caldera floor at a rate of $7-10 \mathrm{~mm} /$ day and when it reached a critical level, the earthquake activity increased steadily until the onset of another sudden deflation event. During the Krafla Fires, the rifting began by failure of the crust beneath the caldera and then migrated along the fissure swarm as indicated by the outwardpropagating earthquake swarms (e.g. Brandsdóttir and Einarsson, 1979). Magma flowed into and filled the open cracks as depicted in Fig. $3 \mathrm{~b}$ and in some instances surfaced to produce an eruption. In total 21 rifting events occurred during the 1975-1984 Krafla volcanotectonic episode (Björnsson, 1985). The first four rifting events occurred in October 1976, January, April, and September 1977, but only the last two resulted in an eruption at the surface. Also, a miniature explosive event through a geothermal borehole produced about $26 \mathrm{~m}^{3}$ of tephra ( $\sim \mathrm{m}^{3}$, DRE) in the September 1977 eruption (Larsen et al., 1979). Other notable rifting events occurred, for example, in March, July, and October 1980, November 1981 and September 1984. The later deflation events produced larger lava eruptions (Fig. 14). After the 1984 event, inflation resumed within the caldera until it ceased in early 1985. Minor, intermittent inflation-deflation cycles were recorded between 1986 and 1989; since then the caldera floor has been subsiding at a slow but steady rate. The total widening of the Krafla fissure swarm during the 9-year volcanotectonic episode was in the order of $900 \mathrm{~cm}$ or almost three orders of magnitude greater than the long-term average spreading rate of the plate boundary in Iceland, which is $1.8 \mathrm{~cm} /$ year (Tryggvason, 1984; Sigmundsson, 2006). The Krafla and Mývatn Fires show that the rifting and spreading along the plate boundary is not a continuous process, but is periodic and confined to relatively short volcanotectonic episodes that make up for previous periods of tectonic quiescence (e.g. Björnsson, 1985).

\section{Summary}

1. Holocene volcanism in Iceland is confined to the neovolcanic zones, which are represented by discrete $15-50 \mathrm{~km}$ wide volcanic zones and belts that collectively cover about one-third of Iceland. Volcanic systems are the principal structure of the volcanic zones and in total there are 30 active systems in Iceland. The volcanic systems are comprised of a fissure swarm or a central volcano or both. A fissure swarm and a central volcano coexist on 12 systems, whereas 7 are only comprised of a central volcano. Nine feature a fissure swarm and a central domain, and two only a central domain. 
2. The diversity of volcanism in Iceland is emphasised by the fact that it features nearly all known volcano types known on Earth. The first order grouping is polygenetic central volcanoes and monogenetic basalt volcanoes. Monogenetic basalt volcanoes are categorized into circular and linear-types and then are grouped into 19 subtypes based on the nature of vent accumulation, eruption style and volcanic environment (i.e. Table 2).

3. The diversity of eruption types is equally impressive and not surpassed by any other volcanic region on Earth. The first order grouping is based on the volume ratio (DRE) of lava and tephra. Effusive eruptions are defined as those with $>95 \%$ of the erupted products emplaced as lava and similarly explosive eruptions are those where $>95 \%$ of the products is tephra. Those with lava/tephra value equal to 0.06-0.94 are defined as mixed eruptions. Although volcanism in Iceland throughout its geologic history is characterized by lava-producing basalt eruptions of Hawaiian and flood lava magnitudes, the abundance of explosive eruptions is high and dominates the record in historical time as well as throughout the Holocene and the Quaternary. The main reason for dominance of explosive eruptions over the last 1100 years is that the most active central volcanoes are situated beneath a glacier or feature ice-capped summits, although high ground water level in volcanically active areas and occurrence of offshore volcanism also play a role. Consequently, phreatomagmatic activity is common. Bulk of historical basalt eruptions is explosive (Surtseyan to Phreatoplinian) in nature due to interaction of magma with external water and for the same reason over 50\% of silicic eruptions are Phreatoplinian or phreatomagmatic. In addition, mixed eruptions of Strombolian to Plinian intensities and silicic Plinian eruptions also feature strongly in the record.

4. Volumes extruded by historical eruptions in Iceland extend over 10 orders of magnitude, from $1 \mathrm{~m}^{3}$ to $\sim 20 \mathrm{~km}^{3}$. The two largest eruptions in the last 11 centuries are the 934-938A.D. Eldgjá and 1783-1784A.D. Laki flood lava eruptions, whereas the largest Plinian and Phreatoplinian eruptions are order of magnitude smaller (i.e. $\left.1-2 \mathrm{~km}^{3}\right)$. The smallest volume $\left(\sim 1 \mathrm{~m}^{3}\right.$, DRE) was produced by a miniature explosive event through a geothermal borehole.

5. The historical record contains 205 eruptive events, which have been identified through chronostratigraphic studies and analysis of historical accounts. Thus, on average there have been 20-25 events per 100 years throughout historical time. Of these 205 historical events, 192 represent individual eruptions and 13 are classified as "Fires". Of the 192 individual eruptions 159 have been verified by identification of their products. Explosive eruptions are most common, comprising 124 events, effusive eruptions account for 14 events and mixed eruptions for 21. "Fires" are grouped separately, because they include two or more eruptions, but often of unknown number, which define an episode of volcanic activity lasting for months to decades. Eight of the Fires are predominantly effusive and the remaining five also include explosive activity that produced widespread tephra layers.

6. The East Volcanic Zone, where the four most active volcanic systems (Grímsvötn, Veidivötn, Hekla and Katla) are located, produced about $80 \%$ of the verified eruptions. The events are divided on the other volcanic zones as follows: Reykjanes-West Volcanic Zone (9\%), North Volcanic Zone (5\%), Öræfi Volcanic Belt (1\%) and Snæfellsnes Volcanic Belt $(0.5 \%)$. The source volcano is not known for about $4.5 \%$ of the eruptions. An apparent stepwise increase in eruption frequency is observed over the last 1130 years that reflects improved documentation of eruptive events with time. Lows in eruption frequency in the 11th and 16th century A.D. are revealed by binning according to centuries. Distinct peaks and lows in eruption frequency appear on decadal scale, best seen in volcanoes below Vatnajökull ice cap which show a periodicity of $\sim 140$ year. Peak strain release periods on the South Iceland Seismic Zone have the same periodicity and coincide with the high frequency eruption periods.

7. The volume of erupted magma over the last 1100 years is $\sim 87 \mathrm{~km}^{3}$ (DRE), where basalt magma accounts for $79 \%$, intermediate magma for $16 \%$ and silicic magma for 5\%. Productivity is greatest, by far, on the East Volcanic Zone as its eruptions have contributed $\sim 79 \%\left(69 \mathrm{~km}^{3}\right)$ of the total volume and two events, the 934-938A.D. Eldgjá and 1783-84 Laki flood lava eruptions account for more than one half $\left(\sim 35 \mathrm{~km}^{3}\right)$. Eruptions and "Fires" on the Reykjanes and West Volcanic Zones produced about $13 \%$ of the magma volume, whereas volcanic events on the North Volcanic Zone and the intraplate belts each account for $2.5 \%$ of the erupted magma volume. Thus, the axial zone (RVZ, WVZ and NWZ) has only produced $15-16 \%$ of total magma volume in the last 1130 years.

\section{Acknowledgements}

We are grateful to Ágúst Gudmundsson and Magnús T. Gudmundsson for constructive reviews and suggestions, which resulted in significant improvements on the initial draft of this manuscript. 


\section{References}

Allen, R.M., Nolet, G., Morgan, W.J., Vogfjörd, K., Bergsson, B.H., et al., 1999. The thin hot plume beneath Iceland. Geophys. J. Int. 137, 51-63.

Bárdarson, G.G., 1929. Geologisk kort over Reykjanes-Halvøen. Det 18. Skandinaviske Naturforskermøde, Copenhagen (Geological map of the Reykjanes peninsula. Report of the 18th Scandinavian Natural Congress), pp. 182-190.

Bárdarson, G.G., 1930. Vulkan-Ausbrucke in Island. I. Vulkan-Ausbrucke in der Gegend der Hekla im jahre 1913. Soc. Sci. Isl. Rit. 1, 31.

Bjarnason, I.T., Wolfe, C.J., Solomon, S.C., Gudmundsson, G., 1996. Initial results from the ICEMELT experiment: body-wave delay times and shear-wave splitting across Iceland. Geophys. Res. Lett. 23, 459-462.

Björnsson, A., 1985. Dynamics of crustal rifting in NE Iceland. J. Geophys. Res. 90, 10151-10162.

Björnsson, A., Johnsen, G., Sigurdsson, S., Thorbergsson, G., Tryggvason, E., 1979. Rifting of the plate boundary in north Iceland 1975-1978. J. Geophys. Res. 84 (B6), 3029-3038.

Björnsson, H., Einarsson, P., 1990. Volcanoes beneath Vatnajökull, Iceland: evidence from radio-echo-sounding, earthquakes, and jökulhlaups. Jökull 40, 147-167.

Blackburn, E.A., Wilson, L., Sparks, R.S.J., 1976. Mechanism and dynamics of Strombolian activity. J. Geol. Soc., London 132, 429-440.

Blake, D.H., 1970. Geology of the Alftarfjordur volcano, a Tertiary volcanic centre in south-east Iceland. Sci. Isl. 2, $43-63$.

Blake, S., 1984. Magma mixing and hybridization processes at the alkalic, silicic, Torfajökull central volcano triggered by tholeiitic Veidivötn fissuring, south Iceland. J. Volcanol. Geotherm. Res. 22, 1-31.

Brandsdóttir, B., Einarsson, P., 1979. Seismic activity associated with the September 1977 deflation of the Krafla center volcano in North-eastern Iceland. J. Volcanol. Geotherm. Res. 6, 197-212.

Carmichael, I.S.E., 1964. The Petrology of Thingmuli, a Tertiary volcano in eastern Iceland. J. Petrol. 5 (3), $435-460$.

Cas, R.A.F., Wright, J.V., 1987. Volcanic Successions: Modern and Ancient. Allen and Unwin, London, 528 pp.

Chenet, A.-L., Fluteau, F., Courtillot, V., 2005. Modelling massive sulphate aerosol pollution, following the large 1783 Laki basaltic eruption. Earth Planet. Sci. Lett. 236, 721-731.

Dvorak, J.J., Dzurisin, D., 1993. Variations in magma supply rate at Kilauea volcano, Hawaii. J. Geophys. Res. 98 (B12), $22255-22268$.

Einarsson, P., 1991. Umbrotin vid Kröflu 1975-1989. In: Gardarson, A., Einarsson, Á. (Eds.), Náttúra Mývatns. Hid íslenska náttúrufrædafélag, Reykjavík.

Einarsson, T., 1949. The rate of production of material during the eruption. The eruption of Hekla 1947-1948. Soc. Sci. Isl. (Reykjavík) IV (2), $1-18$.

Einarsson, S., Jóhannesson, H., 1989. Aldur Arnarseturshrauns á Reykjanesskaga (Age of the Arnarseturshraun lava flow, Reykjanes peninsula, SW-Iceland). Fjölrit Náttúrufrædistofnunar 8, 15.

Einarsson, S., Jóhannesson, H., Sveinbjörnsdóttir, Á.E., 1991. Krísuvíkureldar. II. Kapelluhraun og gátan um aldur Hellnahrauns (The Krísuvík fires. II. Age of the Kapelluhraun and Hellnahraun lava flows, Reykjanes peninsula, Southwest Iceland). Jökull 41, 61-80.

Eiríksson, J., Larsen, G., Knudsen, K.L., Heinemeier, J., Símonarson, L.A., 2004. Marine reservoir age variability and water mass distribution in the Iceland Sea. Quat. Sci. Rev. 23, 2247-2268.

Francis, P., Oppenheimer, C., 2004. Volcanoes. Oxford University Press, Oxford, 521 pp.

Grönvold, K., 1984. Myvatn Fires 1724-1729. Chemical composition of the lava. Science Report 8401. Nordic Volcanological Institute, Reykjavik.

Grönvold, K., Larsen, G., Einarsson, P., Thorarinsson, S., Saemundsson, K., 1983. The Hekla eruption 1980-1981. Bull. Volcanol. 46, 349-363.

Grönvold, K., Óskarsson, N., Johnsen, S.J., Clausen, H.B., Hammer, C.U., Bond, G., Bard, E., 1995. Ash layers from Iceland in the Greenland GRIP ice core correlated with oceanic and land based sediments. Earth Planet. Sci. Lett. 135, 149-155.

Gudmundsson, A., 1986. Formation of crustal magma chambers in Iceland. Geology 14, 164-166.

Gudmundsson, A., 1987a. Formation and mechanics of magma reservoirs in Iceland. Geophys. J. R. Astron. Soc. 91, $27-41$.

Gudmundsson, A., 1987b. Lateral magma flow, caldera collapse, and a mechanism of large eruptions in Iceland. J. Volcanol. Geotherm. Res. 34, $65-78$.

Gudmundsson, A., 1988. Effect of tensile stress concentration around magma chambers on intrusion and extrusion frequencies. J. Volcanol. Geotherm. Res. 35, 179-194.

Gudmundsson, A., 1995a. Ocean-ridge discontinuities in Iceland. J. Geol. Soc., London 152, 1011-1015.

Gudmundsson, A., 1995b. Infrastructure and mechanics of volcanic systems in Iceland. J. Volcanol. Geotherm. Res. 64, 1-22.

Gudmundsson, A., 2000. Dynamics of volcanic systems in Iceland: example of tectonism and volcanism at juxtaposed hot spot and mid-ocean ridge systems. Ann. Rev. Earth Planet. Sci. 28, 107-140.

Gudmundsson, A., Oskarsson, N., Grönvold, K., Saemundsson, K., Sigurdsson, O., Stefánsson, R., Gíslason, S.R., Einarsson, P., Brandsdóttir, B., Larsen, G., Jóhannesson, J., Thordarson, T., 1992. The 1991 eruption of Hekla, Iceland. Bull. Volcanol. 54, $238-246$.

Gudmundsson, M.T., 2003. Melting of ice by magma-ice-water interactions during subglacial eruptions as an indicator of heat transfer in subaqueous eruptions. In: White, J.D.L., Smellie, J.L., Clague, D. (Eds.), Geophys. Monogr. 140. Explosive Subaqueous Volcanism, AGU, pp. 61-72.

Gudmundsson, M.T., 2005. Subglacial volcanic activity in Iceland. In: Caseldine, C., et al. (Eds.), Iceland—Modern Processes and Past Environments. Elsevier; Develop. Quat. Sci. 5, 127-151.

Gudmundsson, M.T., Bjornsson, H., 1991. Eruptions in Grímsvötn, Vatnajökull, Iceland, 1934-1991. Jökull 41, 21-46.

Gudmundsson, M.T., Sigmundsson, F., Björnsson, H., 1997. Ice-volcano interaction of the 1996 Gjálp subglacial eruption, Vatnajökull, Iceland. Nature 389, 954-957.

Gudmundsson, M.T., Pálsson, F., Björnsson, H., Högnadóttir, T., 2002. The hyaloclastite ridge formed in the subglacial 1996 eruption in Gjálp, Vatnajökull, Iceland: present day shape and furture preservation. In: Smellie, J.L., Chapman, M.G. (Eds.), Volcano-Ice Interaction on Earth and Mars. Geol. Soc. Spec. Publ. 202. The Geological Society, London, pp. 319-336. 
Guilbaud, M.-N., Self, S., Thordarson, Th., Blake, S., 2005. Morphology, surface structures, and emplacement of lavas produced by Laki, A.D. 1783-1784. In: Manga, M., Ventura G. (Eds.), Kinematics and Dynamics of Lava Flows. Geol. Soc. Am. Spec. Pap. 396, pp. 81-102. doi:10.1130/2005.2396(07).

Haraldsson, K.Ö., Árnason, S.G., Larsen, G., Eiríksson, J., 2002. The Hekla eruption of 2000-the tephra fall. In: Proceedings of the 25th Nordic Geological Winter Meeting, Abstracts volume, Reykjavík, p. 71.

Hardarson, B.S., Fitton, J.G., Ellam, R.M., Pringle, M.S., 1997. Rift relocation—a geochemical and geochronological investigation of a palaeo-rift in Northwest Iceland. Earth Planet. Sci. Lett. 153, 181-196.

Heiken, G.H., 1971. Tuff rings: examples from the Fort Rock-Christmas Lake valley basin, south-central Oregon. J. Geophys. Res. 76 (23), $5615-5626$.

Höskuldsson, A., Sparks, R.S.J., 1997. Thermodynamics and fluid dynamics of effusive subglacial eruptions. Bull. Volcanol. 59, 219-230.

Houghton, B.F., Wilson, C.J.N., McWilliams, M., Lanphere, M.A., Weaver, S.D., Briggs, R.M., Pringle, M.S., 1995. Chronology and dynamics of a large silicic magmatic system: central Taupo Volcanic Zone. NZ Geol. 23, 13-16.

Jakobsson, S.P., 1979a. Petrology of recent basalts of the Eastern Volcanic Zone, Iceland. Acta Nat. Isl. 26, 1-103.

Jakobsson, S.P., 1979b. Outline of the petrology of Iceland. Jökull 29, 57-73.

Jakobsson, S.P., Jónsson, J., Shido, F., 1978. Petrology of the western Reykjanes peninsula, Iceland. J. Petrol. 19, 669-705.

Jakobsson, S.P., Moore, J.G., 1982. The Surtsey drilling project of 1979. Surtsey Res. Prog. Rep. IX, pp.76-93.

Jóhannesson, H., 1977. Par var ei bærinn sem nú er borgin (The age of two recent lava flows in Hnappadalur, W-Iceland). Náttúrufrædingurinn 47, $129-141$.

Jóhannesson, H., 1980. Jardlagaskipan og próun rekbelta á Vesturlandi (Stratigraphy and evolution of rift zones in West Iceland). Náttúrufrædingurinn $50,13-31$.

Jóhannesson, H., 1983. Gossaga Grímsvatna 1900-1983 í stuttu máli (A brief review of the volcanic activity of the Grímsvötn volcanic system 1900-1983). Jökull 33, 146-147.

Jóhannesson, H., 1984. Grímsvatnagos 1933 og fleira frá pví ári (The Grímsvötn eruption in 1933). Jökull 34, 151-158.

Jóhannesson, H., 1987. Heimildir um Grímsvatnagosin 1902-1910. Fjölrit Náttúrufrædistofnunar 4, 49.

Jóhannesson, H., 1989. Aldur Hallmundarhrauns í Borgarfirdi (Age of the Hallmundarhraun lava flow, Western Iceland). Fjölrit Náttúrufrædistofnunar $9,12$.

Jóhannesson, H., Einarsson, S., 1988a. Aldur Illahrauns vid Svartengi (Age of the Illahraun lava flow, Reykjanes peninsula, SW-Iceland). Fjölrit Náttúrufrædistofnunar 7, 10.

Jóhannesson, H., Einarsson, S., 1988b. Krísuvíkureldar. I. Aldur Ögmundarhrauns og midaldalagsins (The Krísuvík fires. I. Age of the Ögmundarhraun lava and the Medieval tephra layer). Jökull 38, 71-87.

Jóhannesson, H., Sæmundsson, K., 1998. Geological Map of Iceland, 1:500,000. Bedrock Geology. Icelandic Institute of Natural History and Iceland Geodetic Survey, Reykjavík.

Jones, J.G., 1969. Intraglacial volcanoes of the Laugarvatn region, Southwest Iceland, 1. Geol. Soc. London 124, $197-211$.

Jones, J.G., 1970. Intraglacial volcanoes of the Laugarvatn region, Southwest Iceland, 2. J. Geol. 78 (2), 127-140.

Jónsson, J., 1978. Jardfrædikort af Reykjanesskaga. I. Skýringar vid jardfrædikort (Geological map of the Reykjanes peninsula). National Energy Authority Research Report OS-JHD 7831. Orkustofnun, Reykjavík.

Jónsson, J., 1983. Eldgos á sögulegum tíma á Reykjanesskaga (Volcanic eruptions in historical time on the Reykjanes peninsula, SW Iceland). Náttúrufrædingurinn 52, 127-139.

Jónsson, Ó., 1945. Ódádahraun II. Bókaútgáfan Nordri HF, Akureyri, 447 pp.

Jorgensen, K.A., 1987. Mineralogy and petrology of alkaline granophyric xenoliths from the Thorsmork ignimbrite, southern Iceland. Lithos 20, $153-168$.

Kaldal, I., 1985. Vatnaöldur. Náttúrufrædingurinn 55, 137-138.

Kaldal, I., Víkingsson, S., Jóhannesson, H., Saemundsson, K., Torfason, H., 1996. Map of superficial deposits, Vífilsfell 1613/III SA-J, 1:25.000. Iceland Geodethic Survey, National Energy Authority, Gardabær, Hafnarfjördur, Kópavogur, Seltjarnarnes Towns and Reykjavík City.

Karhunen, R., 1988. Eruption mechanism and rheomorphism during the basaltic fissure eruption in Biskupsfell, Kverkfjöll, north-central Iceland. Research Report 8802. Nordic Volcanological Institute, Reykjavík.

Keszthelyi, L., McEwen, A.S., Thordarson, T., 2000. Terrestrial analogs and thermal models for Martian flood lavas. J. Geophys. Res. 105, 15027-15050.

Keszthelyi, L., Thordarson, T., McEwen, A.S., Haack, H., Guilbaud, M.-N., Self, S., Rossi, M.J., 2004. Icelandic analogs to Martian flood lavas. Geochem. Geophys. Geosyst. 5, Q11014, doi:10.1029/2004GC000758.

Kjartansson, G., 1996. A contribution to the morphology of Surtsey. Surtsey Res. Prog. Rep. 2, pp. 125-128.

Kjartansson, G., 1966b. Stapakenningin og Surtsey. Náttúrufrædingurinn 36, 1-34.

Kristjánsson, L., 1982. Geomagnetic polarity mapping in Icelandic lavas. Comparison with ocean-floor magnetic lineations. Earth Evol. Sci. 2, $126-129$.

Lacasse, C., 2001. Influence of climate variability on the atmospheric transport of Icelandic tephra in the subpolar North Atlantic. Glob. Planet. Change 29, 31-55.

Lacasse, C., Garbe-Schönberg, C.D., 2001. Explosive silicic volcanism in Iceland and the Jan Mayen area during the last 6 Ma: sources and timing of major eruptions. J. Volcanol. Geotherm. Res. 107, 113-147.

Lacasse, C., Sigurdsson, H., Jóhannesson, H., Paterne, M., Carey, S., 1995. Source of Ash Zone 1 in the North Atlantic. Bull. Volcanol. 57, 18-32.

Lacasse, C., Karlsdóttir, S., Larsen, G., Soosalu, H., Rose, W.L., Ernst, G.G.J., 2004. Weather radar observations of the Hekla 2000 erutpion cloud, Iceland. Bull. Volcanol. 66, 457-473.

Larsen, G., 1979. Um aldur Eldgjárhrauna (Tephrochronological dating of the Eldgjá lavas in S-Iceland). Náttúrufrædingurinn 49, 1-25. 
Larsen, G., 1982. Gjóskutímatal Jökuldals og nágrennis (Tephrochronology of the Jökuldalur area and its vicinity). In: Thórarinsdóttir, H., Óskarsson, Ó.H., Steinthórsson, S., Einarsson, Th. (Eds.), Eldur er í Nordri. Sögufélag, Reykjavík, pp. 51-65.

Larsen, G., 1984. Recent volcanic history of the Veidivötn fissure swarm, southern Iceland-an approach to volcanic risk assessment. J. Volcanol. Geotherm. Res. 22, 33-58.

Larsen, G., 2000. Holocene eruptions within the Katla volcanic system, south Iceland: characteristics and environmental impact. Jökull 49, 1-28.

Larsen, G., 2002. A brief overview of eruptions from ice-covered and ice-capped volcanic systems in Iceland during the past 11 centuries: frequency, periodicity and implications. In: Smellie, J.L., Chapman, M.G. (Eds.), Volcano-Ice Interaction on Earth and Mars. Geol. Soc. Lond. Spec. Publ., London, pp. 81-90.

Larsen, G., 2005. Explosive volcanism in Iceland: three examples of hydromagmatic basaltic eruptions on long volcanic fissures within the past 1200 years. Geophysical Research Abstracts, vol. 7, 10158, 2005, SRef-ID: 1607-7962/gra/EGU05-A-10158 ${ }^{\odot}$. European Geosciences Union.

Larsen, G., Thorarinsson, S., 1977. H-4 and other acid Hekla tephra layers. Jökull 27, 28-46.

Larsen, G., Gronvold, K., Thorarinsson, S., 1979. Volcanic eruption through a geothermal borehole at Námafjall, Iceland. Nature 278, 707-710.

Larsen, G., Vilmundardóttir, E.G., Thorkelsson, B., 1992. Heklugosid 1991: Gjóskufallid og gjóskulagid frá fyrsta degi gossins (The Hekla eruption of 1991- the tephra fall). Náttúrufrædingurinn 61, 159-176.

Larsen, G., Gudmundsson, M.T., Björnsson, H., 1998. Eight centuries of periodic volcanism at the center of the Icelandic hotspot revealed by glacier tephrostratigraphy. Geology 26, 943-946.

Larsen, G., Dugmore, A.J., Newton, A.J., 1999. Geochemistry of historical-age silicic tephras in Iceland. Holocene 9, $463-471$.

Larsen, G., Newton, A.J., Dugmore, A.J., Vilmundardóttir, E., 2001. Geochemistry, dispersal, volumes and chronology of Holocene silicic tephra layers from the Katla volcanic system, Iceland. J. Quat. Sci. 16, 119-132.

Lorentz, V., 1973. On the formation of maars. Bull. Volcanol. 37, 183-204.

Loughlin, S.C., 2002. Facies analysis of proximal subglacial and proglacial volcaniclastic successions at the Eyjafjallajökull central volcano, southern Iceland. In: Smellie, J.L., Chapman, M.G. (Eds.) Volcano-Ice Interaction on Earth and Mars. Geol. Soc. Spec. Publ. no. 202. The Geological Society, London.

Macdonald, G.A., 1972. Volcanoes. Prentice-Hall Incorporation, Englewood Cliffs, NJ, 510 pp.

Macdonald, G., Abbott, A.T., Peterson, F.L., 1970. Volcanoes in the Sea. University of Hawaii Press, Honolulu, 517 pp.

Macdonald, R., McGarvie, D.W., Pinkerton, H., Smith, R.L., Palacz, Z.A., 1990. Petrogenetic evolution of the Torfajokull volcanic complex, Iceland. 1. Relationship between the magma types. J. Petrol. 31 (2), 429-459.

McDougall, I., Kristjansson, L., Saemundsson, K., 1984. Magnetostratigraphy and geochronology of NW-Iceland. J. Geophys. Res. 89, 70297060.

McGarvie, D.W., 1984. Torfajökull, a volcano dominated by magma mixing. Geology 12, 685-688.

McGarvie, D.W., Macdonald, R., Pinkerton, H., Smith, R.L., 1990. Petrogenic evolution of the Torfajökull volcanic complex, Iceland. II. The role of magma mixing. J. Petrol. 31, 461-481.

Metrich, N., Sigurdsson, H., Meyers, P.S., Devine, J.D., 1991. The 1783 Lakagigar eruption in Iceland, geochemistry, $\mathrm{CO}_{2}$, and sulfur degassing. Contrib. Mineral. Petrol. 107, 435-447.

Miller, D.J., 1989. The 10th Century eruption of Eldgjá, southern Iceland. Research Report 8903. Nordic Volcanological Institute, University of Iceland, Reykjavík.

Moorbath, S., Sigurdson, H., Goodwin, R., 1968. K-Ar ages of oldest exposed rocks in Iceland. Earth Planet. Sci. Lett. 4, $197-205$.

Moore, J.G., Clauge, D.A., 1992. Volcano growth and evolution of the island of Hawaii. Geol. Soc. Am. Bull. 104, 1471-1487.

Mörk, M.B.E., 1984. Magma mixing in the postglacial Veidivötn fissure eruption, South Iceland. A microprobe study of mineral and glass variations. Lithos 17, 55-75.

Ólafsdóttir, R., Höskuldsson, Á., Gronvold, K., 2002. The evolurion of the lava flow from Hekla eruption 2000. In: Proceedings of the 25th Nordic Geological Winter Meeting, Abstracts vol. 149, Reykjavik.

Oman, L., Robock, A., Stenchikov, G.L., Thordarson, T., Koch, D., Shindell, D.T., Gao, C., 2006. Modeling the distribution of the volcanic aerosol cloud from the 1783-1784 Laki eruption. J. Geophys. Res. Atmos. 111, D12209, doi:10.1029/2005JD006899.

Óskarsson, N., Steinpórsson, S., Sigvaldason, G.E., 1985. Iceland Geochemical anomaly: origin, volcanotectonics, chemical fractionation and isotope evolution of the crust. J. Geophys. Res. 90 (B12), 10011-10025.

Pálmason, G., 1973. Kinematics and heat flow in a volcanic rift zone, with application to Iceland. Geophys. J. R. Astron. Soc. 33, 451-481.

Pike, R.J., Clow, G.D., 1981. Revised classification of terrestrial volcanoes and a catalog of topographic dimensions with new results on edifice volume. US Geol. Surv. Open File Rep. OF 81-1038.

Róbertsdóttir, B.G., Larsen, G., Eiríksson, J., 2002. A new detailed stratigraphical and geochemical record of 30 tephra layers from the Hekla volcanic system, Iceland, 2980-850 cal. BP. In: Proceedings of the 25th Nordic Geological Winter Meeting, Abstracts vol. 178, Reykjavík.

Robson, G.R., 1957. The volcanic geology of Vestur-Skaftafellssýsla, Iceland. PhD Thesis. University of Durham, 259 pp.

Rossi, M., 1996. Morphology and mechanism of eruption of postglacial shield volcanoes in Iceland. Bull. Volcanol. 57, 530-540.

Saunders, A.D., Fitton, J.G., Kerr, A.C., Norry, M.J., Kent, R.W., 1997. The North Atlantic Igneous Province. In: Mahoney, J.J., Coffin, M.F. (Eds.), Large Igneous Provinces: Continental, Oceanic, and Planetary Flood Volcanism. Geophys. Monogr. 100. American Geophysical Union, Washington, DC, pp. 45-93.

Sæmundsson, K., 1967. Vulkanismus und Tektonik des Hengill-Gebietes in Südwest-Island. Acta Nat. Isl. 11, 1-105.

Sæmundsson, K., 1972. Jardfrædiglefsur um Torfajökulssvædid (Notes on the geology of the Torfajökull central volcano). Náttúrufrædingurinn 42, 82-99.

Sæmundsson, K., 1974. Fissure swarms and central volcanoes of the neovolcanic zones of Iceland. Geol. Soc. Am. Bull. 85, $495-504$.

Sæmundsson, K., 1978. Fissure swarms and central volcanoes of the neovolcanic zones of Iceland. Geol. J. Spec. Iss. 10, 415-432.

Sæmundsson, K., 1979. Outline of the geology of Iceland. Jökull 29, 7-28. 
Sæmundsson, K., 1991. Jardfrædi Kröflukerfisins (Geology of the Krafla volcanic system). In: Gardarson, A., Einarsson, Á. (Eds.), Náttúra Mývatns. Hid íslenska náttúrufrædifélag, Reykjavík, pp. 25-95.

Sæmundsson, K., 1995. Hengill Geological Map (Bedrock), 1:50,000. Orkustofnun, Hitaveita Reykavikur and Landmælingar Íslands, Reykjavik.

Sæmundsson, K., Einarsson, S., 1980. Geological map of Iceland, Sheet 3, SW-Iceland, 2nd ed. Museum of Natural History and Iceland Geodetic Survey, Reykjavík.

Self, S., Sparks, R.S.J., 1978. Characteristics of widespread pyroclastic deposits formed by the interaction of silicic magma and water. Bull. Volcanol. 41, 196-212.

Self, S., Thordarson, T., Keszthelyi, L., Walker, G.P.L., Hon, K., Murphy, M.T., Long, P., Finnemore, S., 1996. A new model for the emplacement of the Columbia River Basalt as large, inflated pahoehoe sheet lava flow fields. Geophys. Res. Lett. 23, 2689-2692.

Self, S., Thordarson, T., Keszthelyi, L., 1997. Emplacement of continental flood basalt lava flows. In: Mahoney, J.J., Coffin, M.F. (Eds.), Large Igneous Provinces: Continental, Oceanic, and Planetary Flood volcanism. Geophys. Monogr. 100. American Geophysical Union, Washington, DC, pp. 381-410.

Self, S., Widdowson, M., Thordarson, T., Jay, A.E., 2006. Volatile fluxes during flood basalt eruptions and potential effects on the global environment: a Deccan perspective. Earth Planet. Sci. Lett. 248, 518-532.

Sigmarsson, O., Condomines, M., Fourcade, S., 1992. A detailed Th, Sr and O isotope study of Hekla, differentation processes in an Icelandic volcano. Contrib. Mineral. Petrol. 112, 20-34.

Sigmundsson, F., 2006. Iceland Geodynamics, Crustal Deformation and Divergent Plate Tectonics. Praxis Publishing/Springer-Verlag, Chichester, 209 pp.

Sigmundsson, F., Gudmundsson, M.T., 2004. The Grímvötn eruption. Jökull 54, 139-142.

Sigurdsson, H., Sparks, R.S.J., 1978. Rifting episode in north Iceland in 1874-1875 and the eruptions of Askja and Sveinagjá. Bull. Volcanol. 41, $1-19$.

Sigurgeirsson, M.A., 1992. Gjóskumyndanir á Reykjanesi (Tephra deposits on the Reykjanes volcanic system). MSc Thesis. University of Iceland, $114 \mathrm{pp}$.

Sigurgeirsson, M., 1995. Yngra-Stampagosid a Reykjanesi [The Younger-Stampar eruption at Reykjanes, SW-Iceland]. Náttúrufrædingurinn 64, 211-230.

Sigvaldason, G.E., 1979. Rifting, magmatic activity, and interaction between acid and basic liquids: the 1875 Askja eruption in Iceland. Research Report 7903. Nordic Volcanological Institute, Reykjavík, Iceland.

Sigvaldason, G.E., 1982. Samspil vatns og kviku. Öskjugosid 1875 (Water to magma interactions. The Askja eruption of 1875). In: Thórarinsdóttir, H., Óskarsson, Ó.H., Steinthórsson, S., Einarsson, Th. (Eds.), Eldur er í Nordri. Sögufélagid, Reykjavík, pp. 37-48.

Sigvaldason, G.E., 2002. Volcanic and tectonic processes coinciding with glaciation and crustal rebound: an early Holocene rhyolitic eruption in the Dyngjufjöll volcanic centre and the formation of the Askja caldera, north Iceland. Bull. Volcanol. 64, 192-205.

Sinton, J., Gronvold, K., Saemundsson, K., 2005. Postglacial eruptive history of the Western Volacainc Zone, Iceland. Geochem. Geophys. Geosyst. 6 (12), Q12009, doi:10.1029/2005GC001021.

Skilling, I., 2002. Basaltic pahoehoe lava-fed deltas: large-scale charateristics, clast generation, emplacement processes and environmental discrimination. In: Smellie, J.L., Chapman, M.G. (Eds.), Volcano-Ice Interaction on Earth and Mars. Geol. Soc. Spec. Publ. 202. The Geological Society, London, pp. 91-114.

Smellie, J.L., 2000. Lithofacies archtecture and construction of volcanic sequences erupted subglacially. In: Gulick, V.C., Gudmundsson, M.T. (Eds.), Volcano/Ice Interactions on Earth and Mars. University of Iceland, Reykjavík, p. 42.

Sparks, R.S.J., Wilson, L., Sigurdsson, H., 1981. The pyroclastic deposits of the 1875 eruption of Askja, Iceland. Phil. Trans. R. Soc. Ser. A, London 299, 241-273.

Stefánsson, R., Halldórsson, P., 1988. Strain release and strain build-up in the south Iceland Seismic zone. Tectonophysics 152, $267-276$.

Steinthórsson, S., 1978. Tephra layers in a drill core from the Vatnajökull Ice Cap. Jökull 27, 2-27.

Stothers, R.B., 1996. The great dry fog of 1783. Climate Change 32, 79-89.

Stothers, R.B., 1998. Far Reach of the tenth Century Eldgjá eruption, Iceland. Climate Change 39, 715-726.

Swanson, D.A., 1972. Magma supply rate at Kilauea volcano, 1952-1971. Science 175, 169-170.

Thorarinsson, S., 1950. Jökulhlaup og eldgos á jökulvatnasvædi Jökulsár á Fjöllum (Glacier outbursts in the river Jökulsá á Fjöllum). Náttúrufrædingurinn 20, 113-133.

Thorarinsson, S., 1951. Laxárgljúfur and Laxárhraun: a tephrochronological study. Geograf. Ann. 33 (1-2), 1-89.

Thorarinsson, S., 1952a. Hverfjall I. Náttúrufrædingurinn 22, 113-129.

Thorarinsson, S., 1952b. Hverfjall II. Náttúrufrædingurinn 22, 145-172.

Thorarinsson, S., 1958. The Öræfajökull eruption of 1362. Acta Nat. Isl. II 2, 1-100.

Thorarinsson, S., 1963. Askja on Fire. Almenna bókafélagid, Reykjavík, 55 pp.

Thorarinsson, S., 1964. Surtsey—-the New Island in the North Atlantic. Almenna bókafélagid, Reykjavík, 64 pp.

Thorarinsson, S., 1965a. Nedansjávargos vid Ísland (Submarine eruptions of the coast of Iceland). Náttúrufrædingurinn 35, 49-74.

Thorarinsson, S., 1965b. Sitt af hverju um Surtseyjargosid (Some facts about the Surtsey eruption). Náttúrufrædingurinn 35, $153-181$.

Thorarinsson, S., 1966. The Surtsey Eruption, Course of Events and the Development of Surtsey and other New Islands. Surtsey Res. Prog. Rep. 2. The Surtsey Research Society, Reykjavík, pp. 117-125.

Thorarinsson, S., 1967a. The eruptions of Hekla in historical times. In: Einarsson, T., Kjartansson, G., Thorarinsson, S. (Eds.), The eruption of Hekla 1947-1948 I. Soc. Sci. Isl., Reykjavík, pp. 1-177.

Thorarinsson, S., 1967b. The Surtsey eruption and related scientific work. Polar Record 13 (86), 571-578.

Thorarinsson, S., 1967c. Surtsey—the New Island in the North Atlantic. Viking Press, New York, 105 pp.

Thorarinsson, S., 1968. Sídustu thættir Eyjaelda (The last phases of the Surtsey eruption). Náttúrufrædingurinn 38, 113-135. 
Thorarinsson, S., 1970a. Hekla. Almenna Bókafélagid, Reykjavík, 59 pp (in Icelandic).

Thorarinsson, S., 1970b. Ignimbrítid í Thórsmörk. Náttúrufrædingurinn 39 (3/4), 139-155.

Thorarinsson, S., 1974. Vötnin stríd. Saga Grímsvatnagosa og Skeidarárhlaupa (The swift flowing rivers. Grímsvötn eruptions and jökulhlaups in river Skeidará). Bókaútgáfa Menningarsjóds, Reykjavík, 258 pp.

Thorarinsson, S., 1975. Katla og annáll Kötlugosa (Katla and its historical eruptions). Árbók Ferdafélags Íslands 1975, $125-149$.

Thorarinsson, S., 1976. Course of events. In: Einarsson, T., Kjartansson, G., Thorarinsson, S. (Eds.), The Eruption of Hekla 1947-1948 IV (1). Soc. Sci. Isl., Reykjavík, pp. 1-47.

Thorarinsson, S., 1979. On the damage caused by volcanic eruptions with special reference to tephra and gases. In: Sheets, P.D., Grayson, D.K. (Eds.), Volcanic Activity and Human Geology. Academic, New York, pp. 125-159.

Thorarinsson, S., 1981. Jardeldasvædi á nútíma (Volcanic areas of the Holocene). In: Náttúra Íslands, 2nd ed. Almenna bókafélagid, Reykjavík, pp. 81-119.

Thorarinsson, S., Sigvaldason, G.E., 1962. The eruption in Askja 1961. Am. J. Sci. 260, 641-651.

Thorarinsson, S., Sigvaldason, G.E., 1972a. The Hekla eruption of 1970. Bull. Volcanol. 36, 269-288.

Thorarinsson, S., Sigvaldason, G.E., 1972b. Tröllagígar og Tröllahraun (The Tröllagígar eruption 1862-1864). Jökull 22 , 12-26.

Thorarinsson, S., Sæmundsson, K., 1979. Volcanic activity in historical time. Jökull 29, 29-32.

Thorarinsson, S., Steinthórsson, S., Einarsson, T., Kristmannsdóttir, H., Óskarsson, N., 1973. The eruption on Heimaey, Iceland. Nature 241, $372-375$.

Thordarson, Th., 1991. Skaftáreldar 1783-1785. Gjóskan og framvinda gossins (The Skaftár Fires 1783-1785. Tephra fall and course of events). Háskólaútgáfan, Reykjavík, 187 pp.

Thordarson, Th., 2000. Morphology and structure of the 1963-1967A.D. Surtsey lava flow field: results from preliminary observations. Surtsey Res. Prog. Rep. XI, pp. 125-142.

Thordarson, T., Self, S., 1993. The Laki (Skaftár Fires) and Grímsvötn eruptions in 1783-1785. Bull. Volcanol. 55, $233-263$.

Thordarson, T., Self, S., 1996. Sulphur, chlorine and fluorine degassing and atmospheric loading by the Roza eruption, Columbia River Basalt Group, Washington, USA. J. Volcanol. Geotherm. Res. 74, 49-73.

Thordarson, T., Self, S., 1998. The Roza member, Columbia River Basalt group: Agigantic pahoehoe lava flow field formed by endogenoous processes? J. Geophys. Res. 103, 27411-27445.

Thordarson, T., Höskuldsson, Á., 2002. Iceland. Classic Geology in Europe 3. Terra Publishing, Harpenden, UK, 200 pp.

Thordarson, T., Self, S., 2003. Atmospheric and environmental effects of the 1783-1784 Laki eruption, Iceland: a review and reassessment. J. Geophys. Res. 103, 27411-27445, 108(D1). doi:10.1029/2001JD002042.

Thordarson, T., Miller, D.J., Larsen, G., Self, S., Sigurdsson, H., 2001. New estimates of sulfur degassing and atmospheric mass-loading by the 934A.D. Eldgjá eruption, Iceland. J. Volcanol. Geotherm. Res. 108 (1-4), 33-54.

Thordarson, T., Self, S., Óskarsson, N., Hulsebosch, T., 1996. Sulfur, chlorine, and fluorine degassing and atmospheric loading by the 1783-1784A.D. Laki (Skaftár Fires) eruption in Iceland. Bull. Volcanol. 58, 205-225.

Thordarson, T., Miller, D.J., Larsen, G., 1998. New data on the age and origin of the Leidólfsfell cone group in south Iceland. Jökull 46, 3-15.

Thordarson, T., Larsen, G., Steinthorsson, S., Self, S., 2003a. The 1783-1785A.D. Laki-Grímsvötn eruptions. II. Appraisal based on contemporary accounts. Jökull 53, 11-48.

Thordarson, T., Self, S., Miller, D.J., Larsen, G., Vilmundardóttir, E.G., 2003. Sulphur release from flood lava eruptions in the Veidivötn, Grímsvötn and Katla volcanic systems, Iceland. In: Oppenheimer, C., Pyle, D.M., Barclay, J. (Eds.), Volcanic Degassing. Geol. Soc. Lond. Spec. Publ. 213, pp. 103-121.

Thoroddsen, Th., 1907. Skýrslur um Mývatnselda 1724-1729 (Reports on the Mývatn Fires 1724-1729). Safn til sögu Íslands IV, pp. 385411.

Tolan, T.L., Reidel, S.P., Beeson, M.H., Anderson, J.L., Fecht, K.R., Swanson, D.A., 1989. Revision to the estimates of the aerial extent and volume of the Columbia River Basalt Group. In: Reidel, S.P., Hooper, P.R. (Eds.), Volcanism and Tectonism in the Columbia River flood-basalt Province. Geological Society of America Special Paper 239. Geol. Soc. Am., Boulder, Colorado, pp.1-20.

Tómasson, H., 1996. The jökulhlaup from Katla in 1918. Ann. Glaciol. 22, 249-254.

Tryggvason, E., 1973. Seismicity, earthquake swarm and plate boundaries in the Iceland region. Bull. Seism. Soc. Am. 63, 1327-1348.

Tryggvason, E., 1984. Widening of the Krafla fissure swarm during the 1975-1981 volcano-tectonic episode. Bull. Volcanol. 47, 47-69.

Tuffen, H., Gilbert, J., McGarvie, D.W., 2001. Products of an effusive subglacial rhyolite eruption: Bláhnúkur, Torfajökull, Iceland. Bull. Volcanol. 63, 179-190.

Tuffen, H., McGarvie, D.W., Gilbert, J., Pinkerton, H., 2002. Physical volcanology of a subglacial-to-emergent rhyolitic tuya at Raudufossafjöll, Torfajökull, Iceland. In: Smellie, J.L., Chapman, M.G. (Eds.), Volcano-Ice Interaction on Earth and Mars. Geol. Soc. Spec. Publ. 202. The Geological Society, London, pp. 213-236.

Vink, G.E., 1984. A hotspot model for Iceland and the Voring Plateau. J. Geophys. Res. 89, 9949-9959.

Walker, G.P.L., 1959. Geology of the Reydarfjördur area, eastern Iceland. Quart. J. Geol. Soc., London 68, 515-528.

Walker, G.P.L., 1962. Tertiary welded tuffs in Iceland. Quart. J. Geol. Soc., London 118, 275-293.

Walker, G.P.L., 1963. The Breiddalur central volcano, eastern Iceland. Quart. J. Geol. Soc., London 119, $29-63$.

Walker, G.P.L., 1964. Geological investigations in eastern Iceland. Bull. Volcanol. 27, 1-15.

Walker, G.P.L., 1966. Acid volcanic rocks in Iceland. Bull. Volcanol. 29, 375-402.

Walker, G.P.L., 1973a. Lengths of lava flows. Phil. Trans. R. Soc., Ser. A London 274, 107-118.

Walker, G.P.L., 1973b. Explosive volcanic eruptions-a new classification scheme. Geol. Rund. 62, 431-446.

Walker, G.P.L., 1975. Intrusive sheet swarms and the identity of crustal layer 3 in Iceland. J. Geol. Soc. 131, $143-161$.

Walker, G.P.L., 1984. Downsag calderas, ring faults, caldera sizes, and incremental caldera growth. J. Geophys. Res. 89 (B10), $8407-8416$. 
Walker, G.P.L., 1990. Geology and volcanology of the Hawaiian Islands. Pacific Sci. 44, 315-347.

Watkins, N.D., Walker, G.P.L., 1977. Magnetostratigraphy of Eastern-Iceland. Am. J. Sci. 277, 513-584.

White, R.S., Brown, J.W., Smallwood, J.R., 1995. The temperature of the Iceland plume and origin of outward-propagating V-shaped ridges. J. Geol. Soc., London 152, 1039-1045.

Wolfe, C.J., Bjarnason, I.T., Van Decar, J.C., Solomon, S.C., 1997. Seismic structure of the Iceland mantle plume. Nature 385, $245-247$.

Wilson, C.J.N., Houghton, B.F., McWilliams, M.O., Lanphere, M.A., Weaver, S.D., Briggs, R.M., 1995. Volcanic and structural evolution of Taupo Volcanic Zone, New Zealand: a review. J. Volcanol. Geotherm. Res. 68, 1-28. 